\title{
CURBING AFTERMARKET MONOPOLIZATION
}

\author{
John J. Voortman*
}

The United States Supreme Court recently held in Eastman Kodak Company $v$. Image Technical Services ${ }^{1}$ that Kodak's alleged restraint of trade and monopolization of the market for servicing its copiers and other equipment would, if proven, violate the antitrust laws. The importance of the case is that the court so held even though it was conceded, for purposes of the appealed from summary judgment for Kodak, that Kodak had no market power in the market for its original equipment. Three of the Justices dissented. The majority and dissenting opinions reflect the vigorous disagreement over the broader issue of whether competition in replacement parts and repair services (the "aftermarket") ${ }^{2}$ for a single brand of equipment is necessary or even desirable - whether an original equipment manufacturer ("OEM") should have the legal right to prevent others from copying the unpatented OEM created designs of components for its equipment.

This disagreement is reflected not only in the Kodak opinion and earlier opinions dealing with the similar issues, ${ }^{3}$ but also in over seventy years of lobbying efforts, led more recently by OEMs, especially automobile companies, to obtain protection for designs from Congress. That includes 45 bills introduced between 1914 and 1950 with a copyright office bibliography running 160 pages. $^{4}$

A design patent statute protecting designs that are new, original, ornamental, non-obvious and not "dictated by functional requirements" already exists." However, the "non-obvious" and "non-functional" requirements severely limit the applicability of that act to replacement parts. ${ }^{6}$

Modern technology such as computer controlled machine tools apparently makes production of parts in smaller quantities more competitive and reduces the OEMs' cost advantage in obtaining such parts. The result has been a resurgence of OEM interest in legal methods to prevent copying of their parts for the replacement market. The present thrust of their efforts is to obtain copyright protection for the design of the parts that would prohibit copying the

* B.A. Michigan State Univ., 1956; J.D. University of Chicago Law School, 1959; currently a partner at Schiff, Hardin \& Waite, Chicago, Illinois.

1. U.S. — 112 S. Ct. 2072 (1992).

2. The "aftermarket" includes replacement parts and other products and services related to the use of the original equipment. Typically, the manufacturer of the equipment not only manufactures replacement parts but also acts as a wholesaler providing to a dealer organization parts purchased from other manufacturers, usually from the manufacturers who supply parts for assembling the original equipment. The dealer organization retails the equipment and is the equipment manufacturers' choice to do the actual servicing. Situations like $K o d a k$, in which the manufacturer of the equipment seeks to be the exclusive supplier of maintenance for the equipment appear to be uncommon. See infra section III.A.4.a.

3. See infra notes 138-141 and accompanying text.

4. Jay Dratler, Jr., Trademark Protection for Industrial Designs, 4 ILL. L. REv. 887, 904 \& n.94 (1988).

5. 35 U.S.C. $\S 103(1993)$

6. Chrysler Motors v. Auto Body Parts of Ohio, 908 F.2d 951, 952 n.1 (Fed. Cir. 1990) (hearing on appeal from denial of preliminary injunction). Amicus briefs were filed on behalf of plaintiff by the Motor Vehicle Manufacturers Association of the United States and on behalf of defendant by insurance companies, the Consumer Federation of America and by the advocates for highway auto safety. 
designs not only by competitors in the sale of original equipment but also, and probably more important to OEMs, by firms competing in the aftermarket.

Extensive hearings were held on such legislation in 1987 and 1988. That legislation was successfully resisted by a coalition of insurers, who are the principal purchasers of automobile crash parts, consumer groups and independent parts producers. ${ }^{7}$ The effort has not been abandoned. Similar bills were introduced and additional hearings held in $1990 .^{8}$ The issue has also arisen in the Uruguay round of GATT talks in connection with the proposals on industrial design submitted by the Nordic countries and the European Community. ${ }^{9}$ Those proposals would restrict copying replacement part designs and make it more difficult to resist design protection in the U.S. Congress. ${ }^{10}$

House Bill 1790, introduced in 1991, is an effort to compromise with insurers and consumer groups. It is a design copyright bill but excludes from its scope glass for motor vehicles and the elements of a replacement part that "must fit" in order to attach properly to the equipment. ${ }^{11}$. It does not exclude elements of a part that "must match." The language of the Act would appear still to forbid, for example, competing suppliers of replacement fenders from copying any part of the fender other than the parts necessary to attach the fender to the remainder of the frame. The owner of a car needing a single new fender would have the "choice" of buying the replacement part from the OEM or driving a car with unmatched fenders.

This article argues that a combination of the natural advantages of OEMs over independents ${ }^{12}$ in the aftermarket for an OEM's equipment plus the measures OEMs take to raise the costs of their independent competitors result in replacement parts prices which are already too high. Moreover, while it is undoubtedly true that original equipment prices are somewhat lower as a result of the higher aftermarket prices, the net effect is that, except when maintenance or other aftermarket services are sold as part of a package with the sale of the original equipment, the price of equipment plus its maintenance is higher when there is

7. The Industrial Innovation and Technology Act: Hearings on S. 791 Before the Subcomm. on Patents, Copyrights and Trademarks of the Senate Comm. on the Judiciary, 100th Cong., Ist Sess. 98 (1987) [hereinafter Senate Hearings]; Protection of Industrial Designs of Useful Articles: Hearings on H.R. 1179 Before the Subcomm. on Courts, Civil Liberties and the Administration of Justice of the House Comm. on the Judiciary, 100th Cong., 2d Sess. (1988) [hereinafter 1988 House Hearings].

8. H.R. 902, 101st Cong., 2nd Sess. (1990); H.R. 3499, 101st Cong., 2nd Sess. (1990); H.R. 3017, 101st Cong., 2nd Sess. (1990). See Industrial Design Protection: Hearings Before the Subcomm. on Courts, Intellectual Property, and the Administration of Justice of the Comm. on the Judiciary, 101st Cong., 2d Sess. (1990) (hearings on H.R. 902, H.R. 3017 and H.R. 3499 dated May 3, 1990, June 20, 1990 and Sept. 27, 1990, respectively) [hereinafter 1990 House Hearings].

9. Tom Dullforce, EC Proposals Could End U.S. Car Parts Competition, Financial Times, Sept. 11, 1990, § 1, at 7 .

10. Auto Parts Monopoly Costly to Public, Nat'l Underwriter, Apr. 2, 1990, at 36.

11. H.R. 1790, 102d Cong., 2d Sess. $\$ 1002$ (1991). Similar protection is under consideration in Europe. Michael Fawlk, Design Protection in Europe, AIPLA ANTitrust News, June 1992, at 2-3.

12. "Independent" as used herein refers not only to parts suppliers who are not OEMs but also to an OEM attempting to sell replacement parts for brands other than its own. Independents include parts manufacturers, some with their own distributor organizations, and a wide variety of wholesalers and retailers who compete with the OEM and its dealers in the sale of parts and repairs. E.g., Auto parts departments of chain retailers (Sears, Wal Mart); Auto parts stores (National Auto Parts Association, "NAPA"); Specialty chains (Genuine Parts Company as a parts supplier to NAPA). 
a monopoly in the aftermarket than when there is competition in both the original equipment and the aftermarket. If any governmental activity related to replacement parts is desirable, it is action to encourage aftermarket competition; not to create aftermarket monopolies.

To encourage aftermarket competition this article suggests both new general legislation and specific modifications and clarifications of antitrust doctrines designed to make information more readily available to aftermarket competitors and consumers. In addition, this article recognizes the need to reduce aftermarket competitors' costs of buying or manufacturing parts and providing repair services.

\section{THE NEED FOR AFTERMARKET COMPETITION}

It is well accepted that competition, and the marginal cost pricing it encourages, is beneficial because it contributes to a more efficient allocation of resources while protecting consumers from exploitation. However, many argue that competition in aftermarkets is unnecessary or even undesirable because an OEM that has an aftermarket monopoly for its own equipment is subject to restraints on its aftermarket pricing to which monopolists generally are not subject, and the market may benefit from an OEM aftermarket monopoly. While these points may be valid, generally the market benefits significantly from competition in the aftermarket as well as in the original equipment. ${ }^{13}$

\section{A. Aftermarket Competition Should Be Generally Encouraged, Not Suppressed}

Aftermarket prices tend to be monopolistic. They are high in relation to the marginal cost of providing the parts and services and, at least in the case of OEM sellers of replacement parts for their own original equipment, profits are high in relation to the inherent risks of the business. While it is undoubtedly true that some of the monopolistic aftermarket profit margins must be "given back" by OEMs through lower prices on the original equipment, many OEMs will not be required to reduce original equipment prices by the full amount of the monopolistic prices received in the aftermarket. Moreover, high aftermarket prices are unnecessary to create incentives to designing parts, and the combination of competition in the sale of original equipment with a monopoly in the aftermarket will result in a less efficient allocation of resources than competition in both markets. It may also decrease competition in the market for the original equipment.

\section{Aftermarket Prices are Monopolistic}

OEMs' sales of parts in the automotive aftermarket, perhaps the largest aftermarket in the United States, ${ }^{14}$ illustrate the high prices of replacement parts. ${ }^{15}$

13. I have previously treated the impact of copyright law on parts prices. John J. Voortman, Copyrighting Parts Books: The Protection of Parts Information as Industriously Collected or Compiled Data, 10 J.L. \& Сом. 219, 246-54 (1991).

14. While the estimates vary, all support the existence of a multibillion dollar market. Thus retail sales in the United States of auto parts in 1989 were estimated at $\$ 95$ billion dollars of which approximately $\$ 9$ billion were crash parts. Kathleen Heaney, View from Wall Street; Profit seekers should take interest in auto industry of the 1990's Automotive News, Nov. 29, 1989. Sales of replacement parts alone have been estimated at from $\$ 52$ bilion to $\$ 75$ billion dollars per ycar. 1990 
The costs of constructing an automobile from replacement parts, not including assembly costs, has been estimated to range, at the retail level, from 3 to 8 times the cost of buying a fully assembled automobile. ${ }^{16}$

The profitability of the automotive aftermarket for those parts successfully monopolized by the OEMs is reflected in the higher prices of OEM parts compared with the prices of the same parts sold by independents. The dramatic price reductions on replacement parts when they became subject to aftermarket competition compared to the prices of parts not subject to competition that continued to increase also bear out the profitability of monopolization. ${ }^{17}$ Even when the OEM is suffering major losses on the original equipment, aftermarket sales can be profitable. ${ }^{18}$

While no systematic survey has been taken, the materials found in the process of preparing this article reflect that not only in the automotive industry but in many other industries, markets for replacement parts are broadly perceived as particularly profitable. In the aircraft industry the replacement parts market has

House Hearings, supra note 8, at 304. See also Merrill Lynch, Automotive Parts and Tires INDUSTRY REPORT, Report No. 943992, (Investext) (Dec. 20, 1989). General Motors' sales of aftermarket parts in 1989 were estimated at 8 billion dollars. Prudential Bache, General Motors CORPORATION - COMPANY REPORT, Report No. 904411, (Investext) (Jan. 30, 1989). In 1991, spending on maintenance and repair was estimated at $\$ 90$ billion for automobiles, $\$ 16.4$ billion for computers, $\$ 15.6$ billion for telecommunications hardware, $\$ 5.4$ billion of copiers, and $\$ 2.1$ billion for medicai electronics. Joan E. Rigdon, Small Repair Firms Fight Manufacturers, Wall Sr. J., June 22, 1992, at B1 (citing Automotive Services Industry Association, Cannata Report, and D.F. Blumberg \& Associates).

15. Robert Crandall, Vertical Integration and The Market for Repair Parts in the United States Automobile Industry, 16 J. Indus. Econ. 212, 226-29 (July 1968). 1990 House Hearings, supra note 8, at 97-99 (statement of Clarence Ditlow on behalf of The Center for Auto Safety and the Consumer Federation of America) (equivalent non-OEM replacement parts $30 \%$ cheaper than OEM replacement parts). Merrill Lynch, Volvo AB - Company Report, Report No. 900789 (Investext) (Jan. 2, 1989); Fitch Investor Service, Tenneco, Inc. - Company Report, Report No. 802622 (Investext) (Dec. 1, 1987); Drexel Burnham Lambert, Subaru of America - Company Report, Report No. 617062 (Investext) (Nov. 1, 1986). Gail Krueger-Nicholson, The Retailing Climate; Forecast for Independent Aftermarket Automotive Chains, 15 Automotive Marketing, Jan. 1986, at 13.

16. Voortman, supra note 13, at 219 n.1; Foreign Aftermarket Parts and the Quality Question, J. Am. Ins., 1987, at 68; Ashcroft Testifies In Favor of Stronger Federal Auto Theft Laws, U.P.I., July 19, 1983, Regional News (car theft is profitable because parts can be sold for more than the price of the car new); Ned Zeman, Auto Insurers Have Victory Over Volvo, NAT'L UNDERWRITERS, June 13, 1988, at 9 . I have not attempted to obtain cost figures for distributing, inventorying and selling parts in comparison to selling completed cars. I have, however, been unable to find anyattempt by the automotive OEMs to justify the disparity on the basis of cost. Also, it is not apparent why it would be more expensive to transport and sell parts than cars. Parts appear less bulky to transport than completed cars and it is obvious from visits to dealers' parts department and new cars' showrooms that the facilities devoted to the sale of new cars are plusher than parts departments.

17. See generally, Voortman, supra note 13, at 249 n.126; 1990 House Hearings, supra note 8, at 281 (statement of Roger S. Lawson); 1990 House Hearings, supra note 8, at 367 (Appendix A to the Statement of Richard E. Tunney); 1990 House Hearings, supra note 8, at 536 (statement of James E. Ziegler). Mazda estimated that in response to aftermarket competition it had lowered parts prices by 25 to 53 percent. Mary Ellen Porcelli, The Clash Over Auto Crash Parts, 88 Bests' REv., Property-Casualty Edition, June 1987, at 44. General Motors and Ford were reported to have cut prices on crash parts subject to competition by, respectively, 21 to 28 percent and 34 percent. Arthur Flax, Foreign Firms Cut Into Domestic Sheet Metal Sales, Crains Det. Bus., June 8, 1987, \$1 at 19. The Consumer Federation of America has stated that aftermarket competition in crash parts alone saved consumers $\$ 400$ million dollars in 1989. Ruth Gastel, Auto Safety, Insurance INFORMATION INST., July 1990.

18. Carl Rowan, How GM Made A Bad Year Look Good, Wash. Post, Feb. 13, 1983, at G1. 
been characterized as "highly profitable" with spare parts sold at almost six times their original cost. ${ }^{19}$ OEMs made up for unprofitable prices on planes by sales of spare parts. ${ }^{20}$ As an example, a set of turbine blades of an aircraft engine reflect a substantial part of the cost of the entire engine. ${ }^{21}$ Similarly, the aftermarkets for farm machinery ${ }^{22}$ naval pumps and other naval equipment; ${ }^{23}$ trucks; ${ }^{24}$ recreational vehicles; ${ }^{25}$ pleasure boats; ${ }^{26}$ medical machinery; ${ }^{27}$ pumps; ${ }^{28}$ computers; ${ }^{29}$ mining machinery; ${ }^{30}$ furnaces; ${ }^{31}$ powdered coating equipment; ${ }^{32}$ truck trailers; $;^{33}$ oil drilling equipment; ${ }^{34}$ off-road vehicles; ${ }^{35}$ engines; ${ }^{36}$ valves; ${ }^{37}$ and painting

19. Rogerson Aircraft Corp. v. Fairchild Industries, Inc., 626 F. Supp. 1494, 1503 (C.D. Cal. 1986). See also Robert L. Parrish, Engine Life Extension: Aircraft Turbine Engine Component Repair Schemes, Bus. \& Com. Aviation, May 1988, at 70; John H. Sheridan, A Blow for Competition; A Recent Ruling Opens Spare-Parts Market, Industry Wk., Jan. 4, 1988, at 20; Joan M. Feldman, Airframe, Engine Manufacturers Mounting Assault on Costs: Buying and Pricing Aircraft, Part 2, 22 Air Transport World, Aug. 1985, at 34; Eric J. Lerner, Avionics, Unreliability Turns Fighters Into Shop Queens, AerosPaCe AM., Aug. 1985, at 68 (replacement parts "sole source" and "a great money maker - almost pure profit'); Drexel BuRnhaM LAMBERT, Capital Goods - INDUSTRY RePORT, Report No. 941785 (Investext) (Nov. 30, 1989).

20. Feldman, supra note 19.

21. Parrish, supra note 19.

22. U.P.I., June 5, 1986, Regional News (a.m. cycle).

23. A Blow for Competition; Metal Working News, Navy Buying Study, PR NewswIRE, Apr. 18, 1983; George C. Wilson, Civilian Got Action Out of Defense Department, A.P., Sept. 3, 1983, Domestic News Section (OEMs charging greatly inflated prices for replacement parts readily available from other sources, e.g., $\$ 10$ for diodes available from federal supply system for $4 \mathbb{4}$ or from Radio Shack for 994).

24. Lois Therrian, Navistar Tries to Lighten its Load, Bus. WK., Sept. 19, 1988, at 40D.

25. Coast-Distribution: (CRV), the Coast Distribution System Announces Financial Results, Bus. WK., July 17, 1989.

26. Id.

27. Amal Kumar Naj, G.E. Yields to Tiny Rival in Battle Over Servicing Medical Machines, WALL ST. J. Mar. 18, 1991, at B1 (OEMs "often made little money on equipment sales but relied instead on service contracts for their profits ....'); Rigdon, supra note 14 (independent's hourly labor charges are about $25 \%$ of OEM's charges).

28. Gould Pumps Reports Tenth Consecutive Increase in Sales and Earnings, PR NEwswIRE, Oct. 18, 1989.

29. Mark Halper, Rivals Open $\$ 100$ Rebates on $64 K$ Home Computers: Say Commodore Readies 16K VIC, 29 Electronic News, Apr. 18, 1983, at 61.

30. John A. Jones, Harnishfeger Pulls Ahead on Two Leading Business Lines, Investors Dally, Feb. 12, 1990, at 34. Shearson Lehman Bros. Holdings, Inc., Harnishfeger Industries - Company REPORT, Report No. 830789, (Investext) (Dec. 19, 1988).

31. International Heater Co. v. Commissioner, 10 T.C.M. (CCH) 656 (June 29, 1951 ).

32. Shearson lehman Bros. Holdings, Inc., Nordson Corporation -Company Report, Report No. 95247 (Investext) (Feb. 27, 1990); Paine Weber, Nordson Corporation - Company Report, Report No. 933864 (Investest) (Oct. 14, 1989).

33. Wertheim, Schroder, TERex Corporation - Company RePort, Report No.945650 (Investext) (Jan. 3, 1990).

34. ROBERT W. Barrett \& Co., InC., Baroid Corporation - Company Report, Report No. 1047200 (Investext) (Dec. 21, 1990).

35. Merrill Lynch, Caterpitlar, Inc. - Company Report, Report No. 924751 (Investext) (July 27, 1989); Donaldson Lufkin \& Jenrette, InC., Clark Equipment Company Research Bulletin, Report No. 400330 (Investext) (Jan. 9, 1984).

36. Morgan Stanely \& Co., InC., IMO Industries - Company Report, Report No. 916781 (Investext) (May 17, 1989); Oppenheimer \& Co., InC., TeXtron, Inc. - Company Report, Report No. 616597 (Investext) (Nov. 20, 1986).

37. Alex. Brown \& Sons, Keystone International - Company Report, Report No. 616964 (Investext) (Nov. 19, 1986). 
equipment;"38 are generally characterized as "higher margin," "higher profit" or words of similar import. The foregoing does not purport to be a scientific survey of aftermarket prices, but the frequent reiteration, in reference to a wide variety of industries, that replacement parts are high margin products without any contrary indication is very suggestive of a general rule.

The high margins generally attributed to aftermarkets are also inconsistent with the theory that aftermarket margins must be high because the business is unusually risky. The common perception appears to be that aftermarkets are relatively stable. ${ }^{39}$

\section{The Combined Cost of the Original Equipment and its Maintenance.Will Increase if the Aftermarket is Monopolized}

Two broadly applicable arguments challenge the contention that aftermarket competition is needed to protect buyers from paying monopolistic prices. First, buyers purchase equipment to perform the function for which it is designed. If they are rational, they will, in making a decision on which brand of original equipment to purchase, consider the total cost of performing that function including the cost of operating the equipment. This will tend to restrain aftermarket prices because high maintenance prices will reduce the demand for that brand. That was the basic argument made by defendant in Kodak and by the Antitrust Division of the United States Department of Justice which filed an amicus brief on behalf of the defendant. ${ }^{40}$ The dissent by Justice Scalia joined by Justices $O^{\prime}$ Connor and Thomas accepted that argument for the most part. ${ }^{41}$

Second, even if it is possible to obtain monopolistic aftermarket prices, the prospects of the monopolistic profit combined with competition in the sale of original equipment will force original equipment price reductions. Both these factors should reduce the ability to profit from aftermarket monopoly but not, I suggest, to the extent of fully eliminating the monopolistic profit.

38. Prudential Bache Securities, Graco, Inc. - Company Report, Report No. 708179 (Investext) (May 1, 1987).

39. Auto Parts Suppliers Under Pressure in 1990 Says Analyst, PR Newswire (Apr. 3, 1990) (Duff and Phelps expect replacement parts suppliers to outperform the market because of "more stable industry fundamentals when compared with other economically sensitive sections."'). MERRILL Lynch, Automotive Parts \& TIRes - Industry Report, Report No. 943992 (Investext) (Dec. 20, 1989) ("We look for replacement parts stocks to outperform the market during an economic downturn but to lag during an economic boom."); Drexel. Burnham Lambert, Inc., Sundstrand Corp. CoMPany RePORT, Report No. 932371 (Investext) (Sept. 19, 1989); A Company Reborn, Forbes, Jan. 9, 1989, at 156; Smith Barney, Harris Upham \& Co., Inc., Sealed Power Corp. - Company Report, Report No. 504734 (Investext) (Apr. 26, 1985). But see, Donaldson Lufkin \& JenretTe, INC., The Automotive Market - Industry RePORT, Report No. 405519 (Investext) (Apr. 10, 1984) (finding that automotive aftermarket "failed miserably". as a "safe harbor" during the last recession).

40. Kodak, $112 \mathrm{~S}$. Ct. at 2081-82, $2084 \mathrm{n} .16$. That argument was also raised in the hearings on the Design Copyright Bill. 1988 House Hearings, supra note 6, at 103-04. It was given by Assistant Attorney General Baxter as a reason for dropping the tie-in charges against Mercedes Benz of North America. See Government Would Rather Not Win This Lawsuit, PR Newswire, Mar. 23, 1982. See also, Parts and Electric Motors, Inc. v. Sterling Elec., Inc., 866 F.2d 228, 236 (7th Cir. 1988) (Posner, J. dissenting).

41. Kodak, 112 S.Ct. at 2097. 
a. OEMs' Ability to Exploit Aftermarket Monopolies Will Not be Fully Restrained by Buyer Resistance to Brands with High Maintenance Costs

The impossibility, absent binding contractual provisions, of knowing each OEM's future aftermarket pricing policies and the cost of obtaining complete information on even their current pricing policies suggests that buyer consideration of maintenance costs cannot fully restrain OEM aftermarket pricing. As stressed by the opinion of the court in Kodak, ${ }^{42}$ if the threat of the loss of sales of original equipment is to be a fully effective restraint on aftermarket pricing, it is essential that buyers have reasonably accurate information about costs of repair and maintenance of the equipment sold by competing OEMs as well as the equipment purchased. This will often be expensive, indeed impossible, to obtain.

The critical knowledge is information, at the time of purchasing the original equipment, concerning the seller's future aftermarket prices. Absent warranty or other contractual provisions legally restricting the OEM's future pricing policies, that is information that the buyer cannot have. While the OEM may have a long history of moderate pricing of replacement parts and/or services, a management change in ordinary course or as a result of a takeover or a financial emergency requiring immediate revenue regardless of long term consequences may result in a decision to increase aftermarket prices as an immediate solution to the problem.

It will often be expensive, and sometimes impossible, to obtain even reasonably complete information on current aftermarket pricing policies before making a decision on the brand of original equipment to purchase. OEMs will not necessarily provide copies of their parts price lists and pricing policies to anyone who asks, and even when they do, those will only be the prices of the OEM. When, as is usually the case, the OEM sells through dealers, they will be free to charge whatever price they choose when selling parts or making repairs.

While published information, such as that found in Consumer Reports, is relevant to the cost of maintaining competing brands of automobiles, even that is much less than the information which would be required to compare the costs of operating different models over their expected lifetimes. Information as to the cost, other than energy costs, of maintaining and operating the horde of other consumer appliances such as refrigerators, washing machines, air conditioners, furnaces, lawn mowers, etc., appears even less available than information on automobile repair costs. ${ }^{43}$

Large purchasers of the equipment in the past may have internal information on maintenance costs of some brands, but keeping such records also involves significant administrative expenses. Smaller purchasers will often conclude that the record keeping or other methods of obtaining information are not worth the cost since the OEM is free to change its policies in any event.

42. Id. at $2085-87 \&$ n. 20 .

43. Insurance companies adjust their charges for collision insurance, in part, based on their estimate of the cost of repairing particular brands of vehicles. Thus, to some extent, the cost of collision insurance is a surrogate for the cost of replacement parts. Gastel, supra note 17. I have been unable to obtain statistics on the percentage of new car buyers who utilize the relatively easy device of calling their insurance company prior to making a decision to purchase a new car to compare the relative costs of collision insurance for the brands under consideration. 
It is true that the desire to sell the original equipment can serve as a restraint on aftermarket prices even though some buyers are not well informed of the OEM's pricing policies. The desire to sell to the buyers who are well informed will restrain the OEM's prices, but, as the court noted in Kodak, ${ }^{44}$ only to the extent that the OEM is not in a position to price discriminate between the two classes. If, as is frequently the case, the smaller, less well informed buyers or buyers who have integrated their operations with the unique features of one brand of equipment can be charged a higher price than the larger, better informed buyers or buyers who are not tied into a particular brand, then the information that the larger buyer may have will have little effect on the prices to the sinalier buyers. ${ }^{45}$ The dissent in Kodak seemed not to disagree with the conclusions of the majority regarding the effect of aftermarket monopolies on consumers, but suggested that these effects were normal and unavoidable and should not be the concern of the antitrust laws. ${ }^{46}$

Because buyers cannot rely on a continuation of favorable aftermarket pricing policies, even the best informed buyers of the original equipment must discount the benefits of such policies to reflect the fact that the benefits may never occur. The costs, and sometimes impossibility, of obtaining information on even current maintenance costs of equipment will also result in buyers being less than completely sensitive to future parts and servicing costs when buying original equipment. Because rational buyers will discount the benefits of future maintenance cost savings, firms with aftermarket pricing policies who are competing with firms with lower aftermarket pricing policies will not be forced, by buyers' concerns with maintenance costs, to lower their original equipment prices by the full amount of the added profit in the aftermarket. Therefore, it will be in the interest of OEMs and their dealers to charge what the market will bear in the aftermarket and price their original equipment accordingly.

b. Competition in Original Equipment Will not Lower Original Equipment Prices by the Full Amount of the Monopolistic Aftermarket Prices

Competition from other OEMs will also tend to force lower original equipment prices to compensate for monopolistic aftermarket prices. When each unit of original equipment sold will predictably result in additional aftermarket sales at a monopolistic profit, OEMs will reduce profits on original equipment or possibly even sell at a loss to increase aftermarket sales. ${ }^{47}$ OEM's will not be

44. Koduk, $112 \mathrm{~S} . \mathrm{Ct}$. at 2086-87.

45. The opinion of the court in Kodak relied on these factors to conclude that the servicing monopoly which Kodak sought to achieve could have negative effects on customers. It should be noted that the Robinson-Patman Act's restrictions on price discrimination will generally not be applicable to protect the less sophisticated buyers or those who have made a commitment to a particular brand. This is so because they will usually not be competitors, and the Act's protection against injury to buyers (commonly referred to as secondary line injury) is applicable only to discrimination between competitors. See infra section III A.1.f.

46. Id. at 2096-99.

47. Parrish, supra note 19; Dexter Hutchins, Caterpillar's Triple Whammy, Tne, Oct. 27, 1986, at 91 (to protect replacement parts business Caterpillar has always been willing to cut original equipment prices and lock in the replacement customer). See Allan Zelenitz, Below - Cost Original Equipment Sales as a Promotional Means, Rev. of Econ. ANd Stat. Nov. 1977, at 438, 446. Allan Zelenitz, The Attempted Promotion of Competition in Related Goods Markets, ANTrTrust BulL., Spring 1980, at 103, 113-14 [hereinafter Zelenitz 1980] (independent sparkplug manufacturers' sales to automobile OEMs at below cost treated as promotional expense because the use of a brand of plug in original equipment was essential to success in the plug aftermarket). 
equally able to utilize that strategy because they will not be equally able to employ the various devices for monopolizing the aftermarket that are described in this article. ${ }^{48}$ The original equipment prices of OEMs that are less able to do so will not force down the original equipment prices of competitors more successful at monopolizing the aftermarket by the full amount of the monopolistic aftermarket prices.

The analysis in subsections $a$. and $b$. above, suggests that in an industry in which it is possible to monopolize all or a part of the aftermarket, aftermarket prices will be monopolistic, but that competitive pressure will require OEMs to reduce original equipment prices. Aftermarket prices will be high and original equipment prices low in relation to marginal costs. While not all firms with monopolistic aftermarket prices are able to charge monopolistic prices for the combination of original equipment and aftermarket parts or services, that will be the case for those firms, generally the larger firms, that are most able to monopolize the aftermarket.

\section{An OEM or Dealer May Raise Parts Prices in the Process of Going Out of Business}

The restraining effect of original equipment competition on both original equipment and aftermarket prices that tends to limit the harm which aftermarket monopolies would otherwise do is absent when an OEM concludes that there is neither a long run future for its brand nor the likelihood of selling out as a going business. The OEM has little further incentive to refrain from charging whatever the traffic will bear in the aftermarket.

More frequently, though on a smaller scale, the same will be true of the OEM's dealers. An OEM with numerous dealers will, on a continuing basis, have some who want to leave the business to retire or for other reasons. Selling the dealership will not always be the way to obtain the highest recovery for the business. For example, the dealership's good will may be principally the good will of the owner as an individual and not effectively transferrable to someone else with the sale. The owner, particularly if the dealership has substantial protection from intrabrand competition, may believe that the best way to take money out of the dealership is to increase margins on original equipment, parts and service and accept the resulting decline in market share. That conflicts with the OEM's interest, but there are limits on the OEM's ability to protect itself. Maximum price fixing by the OEM would constitute a violation of Section 1 of the Sherman Act under the Rule of Albrecht v. The Herald Companys and replacing the dealer may be difficult. Contractual protections of the dealer, statutory provisions, ${ }^{30}$ and concern about lawsuits for alleged antitrust violations may make pruning dealership organizations risky and expensive. Finally, satisfactory new dealers may be difficult to find. That is particularly true if the old dealer is not terminated because it is then impossible to offer the new dealer any territorial protection.

48. For example, some firms will use more unique parts, which are more often successfully monopolized than standard parts.

49. 390 U.S. 145 (1968).

50. E.g., Automobile Dealers Day in Court Act, 15 U.S.C. $\$ 1221$ et seq. (1992) and State Franchise Acts. 


\section{Artificially High Parts Prices Result in Waste}

When maintenance costs are artificially high, equipment will be junked before the end of what its useful life would be if both maintenance and original equipment were priced at marginal cost. Competitive or lower than competitive prices for the original equipment combined with monopolistic aftermarket prices increase the probability that the equipment will be junked prematurely.

\section{Purchasing Decisions Will be Less Well Informed}

One of the consequences of artificially low original equipment prices combined with monopolistic aftermarket prices is to shift part of the total cost of using the equipment from the price of the equipment, a price that is known when the equipment is purchased, to the future. That makes it more difficult not only for the buyer to compare competing brands, but also to determine whether it is economical to invest in equipment of that kind. One who buys under the assumption of competitive aftermarket pricing will be misled by the artificially low initial price of the original equipment as to the total cost of using it over its lifetime. The purchase may not be economically justified when the total cost is considered. This is particularly likely when the buyer has some general knowledge of maintenance costs for that type of equipment sold at competitive prices, but is unaware of the extent of the monopoly in the aftermarket for a specific OEM's brand of equipment. That is much less likely when the existence of the OEM's future aftermarket monopoly is disclosed, for example, by the fact that the buyer made an express agreement to purchase replacement parts or services from the OEM.

\section{Entry Into the Market for the Original Equipment Will be More Costly}

Entry into a market in which low original equipment prices are subsidized by high aftermarket prices will be more costly than if prices in both markets are competitive. The cost of entry into the business of selling original equipment and parts or complete maintenance will be increased because the new entrant must wait for a return on investment until sufficient time after sale of the original equipment for the original equipment to wear out and become a substantial market for repairs. Assuming, as is commonly believed, that increasing the size of the investment required tends to make entry more difficult, the effect of an aftermarket monopoly will be to restrict entry. ${ }^{51}$

\section{Buyers May be Injured by Monopolistic Prices Even if the OEM is Making a Business Mistake}

Even if it were conceded that monopolistic aftermarket prices are always a mistake in the long run, sellers will make mistakes. Moreover, firms probably have a bias in favor of taking profits now and taking their chances with the future. That is particularly likely when a firm is in financial difficulty. A firm's decision to take some quick profits by raising aftermarket prices will injure existing owners even if it turns out to be an unprofitable tactic in the long run.

51. The assumption that higher capital requirements delay entry has been questioned. George J. Stigler, Monopoly and Oligopoly by Merger, 40 AM. Econ. REv. 23, 27 (May 1950). 
The expectations of buyers who based their purchasing decisions on cost projections assuming competitive aftermarket prices will find their expectations frustrated.

\section{Aftermarket Monopoly is Not Necessary to Spur Design Creativity}

The OEM may have spent substantial resources deciding on the specifications and design of the equipment and the parts of the equipment, particularly the unique parts. It is entitled to a reward for its commercially successful design work. Without the prospect of a reward, the company would have less incentive to spend resources on design. The grant of a monopoly by law would provide the incentive. However, this gives limited, if any, support to giving OEMs monopoly rights, vis a vis aftermarket competitors.

The design of parts is largely dictated by the performance and appearance desired for the original equipment and the need to mesh with other components of that equipment and not by any separate consideration of the superior appearance or performance of the parts standing alone. This is obviously true, for example, of crash parts for automobiles and probably for a great majority of the structural aspects of the design of parts. The parts are not inherently superior to any other part except for use in the particular brand of original equipment for which they are designed because they are designed to work together with the other components. No persuasive reason exists to treat such designs as a property right of the OEM.

Where the OEM creates a unique design of a part that is superior, standing alone, a justification exists for a monopolistic price and for protection against competition from copies. Admittedly patent protection will not always provide such protection. However, parts are designed principally to create the original equipment and, if the OEM is protected against copying the superior design for competing original equipment, lack of protection against copying by aftermarket competitors is, at most, a minor threat to the incentive for creating such designs. Further, just as OEMs' pricing of replacement parts is partially restrained by the fact that sophisticated buyers will pay less for the brands that have a reputation for requiring high cost maintenance and repair, to at least the same extent, reduction in maintenance costs resulting from lower replacement parts prices will permit a higher price for the original equipment. That should occur regardless of whether the economical repair is made with parts provided by the OEM or by its aftermarket competitors.

\section{B. Benefits of Aftermarket Monopolies}

While aftermarket monopolies should generally be avoided there are circumstances in which they may contribute to economic efficiency and be beneficial to consumers.

1. An Aftermarket Monopoly May Permit Efficiency Enhancing "Metering" when the OEM also has Monopoly Power in the Market for the Original Equipment

"Metering" as used herein refers to a method of determining the amount the equipment is used for purposes of charging according to use. It is employed, for example, when equipment is leased at rates based on its usage. Some buyers 
will find a product more attractive and necessary than others and, therefore, be willing to pay a higher price. Sellers, if able, would benefit from charging each buyer the highest price that that buyer would be willing to pay for the product as long as the price is in excess of the seller's marginal cost. In a competitive market such pricing is impossible. Even monopolists will usually find it difficult to charge buyers widely varying prices because of arbitrage - the buyer paying the lower price would resell to the buyer being charged the higher price forcing the price down toward the lower price. The difference between the seller's actual price and the higher price some buyers would be willing to pay is sometimes referred to as "consumer surplus."

If, as is often the case, the amount buyers are willing to pay in order to obtain the use of the equipment depends on the amount they will use the equipment, then the seller with an original equipment monopoly may be able to avoid arbitrage and increase its profits by retaining ownership of the equipment, leasing it and charging a rental based on use. Leasing and directly metering use, however, will usually involve substantial costs of equipment and administration. It will also increase the OEM's capital requirements because the OEM is receiving no immediate return of capital at the time of the lease but must await a return by the payment of rent over time. In addition, typically lessees will not maintain and handle leased equipment as carefully as equipment they own with the result that the leased equipment will require more maintenance and repair. When the OEM has an aftermarket monopoly and the need for maintenance tends to increase with the amount it is used, taking a monopoly profit in the aftermarket can serve as a surrogate for direct methods of charging for use, without all the disadvantages of leasing.

The metering made possible when an OEM has a monopoly of the aftermarket may have net positive effects when the OEM also has a monopoly of the original equipment. Profit maximization by the monopolist selling to everyone at the same price will result in prices above marginal costs. and correspondingly lower production levels than under competition. The monopolist that can discriminate based on the price each purchaser is willing to pay will sell to even those buyers willing to pay only the sellers marginal cost. Price discrimination will tend to increase production towards the competitive level.

There are losers under this kind of price discrimination - the buyers who would still have had some consumer surplus when purchasing at the uniform monopoly price. There are also winners. They are the monopolist, to whom the surplus is diverted, plus the buyers who purchase at the discriminatory lower price, but would not have done so at the uniform monopolistic price. ${ }^{52}$ Putting aside the probably higher cost of administering the discriminatory pricing structure

52. See Tyler A. Baker, The Supreme Court and the Per Se Tying Rule: Cutting the Gordion Knot, 66 VA. L. Rev. 1235, 1257-74, 1276-81 (1980). In Jefferson Parrish Hospital v. Hyde, 466 U.S. 10 (1984), the majority opinion viewed the "discrimination" permitted by charging according to use negatively as it "can increase the social cost of market power." Id. at 14. In contrast, the four justice minority opinion advocated the abandonment of the per se rule for tying arrangement arguing, as suggested here, that price discrimination may decrease the economic cost of market power. Id. at 36-37, 41. Nevertheless, Justice Scalia's dissenting opinion in Kodak seems to recognize, without necessarily agreeing with, the fact that the court has treated a monopolist's ability to discriminate in price as a negative rather than, as here, a positive factor. Kodak, 112 S.Ct. at 2095. 
there is a net gain. The gain to the monopolist would equal the loss of the consumer surplus to the buyers who would have bought at a uniform monopoly price. The benefit to the buyers who are enabled to purchase only because of the discrimination resulting from the ability to meter, plus the monopolist's gain on those sales, is a net gain. ${ }^{53}$

Metering, and charging according to use, may also serve as a risk allocation device. Potential buyers, particularly for new products, may be uncertain not only about the quality of the new product but also about the utility of the product in their operations - will they be able to use it enough to justify the investment. By reducing the price of the original equipment and obtaining instead a higher price for its use by the buyers, the OEM absorbs part of the risk. ${ }^{54}$ Therefore, an aftermarket monopoly may be an administratively economical way of accomplishing efficiency enhancing metering. ${ }^{35}$

\section{OEM Aftermarket Monopolies may Facilitate Quality Control and New Entry into the Market for the Equipment}

When repairs are made under the seller's warranty, the seller will normally insist on the use of its parts and on doing the warranty work or having it done by its dealers. ${ }^{56}$ The Seller is "paying" for the repair and, to minimize its future warranty expense, it will wish to be certain of the quality of the repairs.

Setting specifications for replacement parts to be used for warranty repairs may be a practical alternative method to insuring parts quality in some instances. ${ }^{57}$ However, it is apparent that administering such a program and policing compliance will involve substantial costs. The costs may well increase the price of the repairs to consumers by an amount greater than the increase resulting from an OEM monopoly.

The OEM's concern with the quality of repairs on its equipment is not limited to repairs made during the warranty period. Repairs with inferior parts can result in failures that the owner may attribute to the equipment itself rather than to the parts used in the repair. The damage done to the reputation and salability of the original equipment is particularly likely to be serious when the equipment is novel and untested or the OEM is attempting to break into a market against already established firms. Under such circumstances, permitting the OEM to monopolize the aftermarket, at least for a period, may facilitate entry into the original equipment market and thus increase competition. ${ }^{58}$

53. See generally Joseph Gregory Sidak, Debunking Predatory Innovation, 83 CoLUM. L. REV. 1121 , 1126-35 (1983). Sidak argues that technological tie-ins - changing the design of equipment so that only the OEM will be able to provide parts - contributes to economic efficiency. His article was written in response to Janusz A. Ordover \& Robert D. Willig, An Economic Definition of Predation: Pricing and Product Innovation, 91 Y Ale L.J. 8 (1981). See also, Janusz A. Ordover et al., Predatory Systems Rivalry: A Reply, 83 Colum. L. Rev. 1150 (1983).

54. See Sidak, supra note 53, at 1135; M.L. Burstein, A Theory of Full Line Forcing, $55 \mathrm{Nw}$. U. L. REv. 62 (1960-61).

55. See Sidak, supra note 53 , at $1137-40$.

56. Such insistence is sometimes illegal. See infra note 68.

57. The 1977 amendments to the Clean Air Act, 42 U.S.C. 7522,7541 (1983 \& Supp. 1992) in effect required OEMs to certify the quality of competitors' emission control parts rather than the use of OEM parts.

58. Kodak, 112 S. Ct. at 2094 (Scalia, J. dissenting); Fortner Enterprises, Inc. v. United States Steel, 394 U.S. 495, 514 n.9 (1969) (White, J. dissenting); United States v. Jerrold Electronics Corp., 187 F. Supp. 545, 556-58 (E.D. Pa. 1960), aff'd per curiam, 365 U.S. 567 (1961); Sidak, supra note 53, at 1136-37. 
It is apparent from the discussion in subsections 1 and 2 above that neither general encouragement nor categorical condemnation of all aftermarket monopolies is appropriate. A case by case approach is required. It is necessary to weigh not only the advantages and disadvantages of a monopoly of a particular aftermarket, but if the monopoly is considered undesirable, to consider the costs as well as the benefits of prohibiting the conduct that leads the OEM to obtain monopolistic profits.

\section{THE SOURCES OF OEMS' POWER TO OBTAIN MONOPOLISTIC AFTERMARKET PROFITS}

Because buyers' preferences for OEM parts and services and lower OEM costs, competition from independents will rarely force aftermarket prices to the OEM's marginal cost. Underlying those factors is the cost of obtaining parts information and the OEM's higher volume, particularly for parts.

\section{A. Buyer's Preference for OEM Parts and Servicing}

Price and availability being equal, consumers will normally prefer parts provided by or under the auspices of the OEM. ${ }^{59}$ Parts used by OEMs in producing original equipment often become more saleable even for purposes of repairing other brands of original equipment. ${ }^{60}$ In the case of sparkplugs, for example, use by an OEM has been so essential to sales of plugs in the aftermarket that plug manufacturers sold to OEMs at far below cost in the expectation of recovering the losses in the aftermarket. ${ }^{61}$

Lack of information and the expense, in money and inconvenience, of obtaining information about the relative quality of competing parts and services lies at the root of this preference. ${ }^{62}$ Individual consumers probably do not even know the identity of most of the manufacturers of the parts used to repair their equipment, much less are they in a position to test the quality of the parts before they are purchased.

Firms with in-house capacity for repair and maintenance work and individual do-it-yourselfers will be aware of the brand used at least for the maintenance which they perform in-house. However, that will rarely include all parts. Even as to the parts used for in-house repairs, where the brand of the part is known, some or all of the specifications may be unavailable. ${ }^{63}$ The equipment users will rarely have the kind of equipment necessary to determine all the parts specifications or otherwise establish their quality prior to purchasing and using the parts. That is even more true of parts purchased by individual consumers. Even when parts specifications are readily available, examining and comparing the specifications of a multitude of parts for numerous brands by personnel with the required skills will be costly.

59. Tibor Scitovsky, Capitalism and Monopolistic Competition: The Theory of Oligopoly; Ignorance as a Source of Oligopoly Power, 40 AM. Econ. Rev. 48 (May 1950).

60. Johnson Brauns Company v. Commissioner, 24 TCM 1542 (1965).

61. Ford Motor Co. v. United States, 450 U.S. 562 (1972); Harry L. Hanson \& Marcell N. Smith, Champion Case: What is Competition?, 29 HaRv. Bus. Rev. 89 (1951).

62. George J. Stigler, The Economics of Information, 69 J. Pol. Econ. 213 (1961).

63. Manufacturers may refuse to make the specifications of their parts available. Senate Hearings, supra note 8, at 133 (statement of the National Association of Insurance Commissioners); 1988 House Hearings, supra note 8, at 192 (testimony of William S. Thompson). 
The logical solution to the owner's problem of lack of objective information will often be to take the repair business to the OEM's dealers or, if to an independent repair facility, to insist on the use of the OEM's parts. The owner knows of the OEM and has felt sufficiently confident in its reputation to buy the equipment. In contrast, all the owner may know about independent parts suppliers is what appears in the OEM's advertisements for "genuine" OEM parts and horror stories about the consequences of buying cheap parts from fly-bynights. At least the OEM parts presumably will have been designed or selected to mesh with the other components of the original equipment. The owner cannot be confident that that is true of competing parts which are produced by firms seeking to sell parts for a variety of brands. The OEM, moreover, will have greater incentive to use quality parts than an independent parts supplier. It has an established business in both the original equipment and aftermarket to protect against the damage to its goodwill that would result from problems created by substandard parts.

In addition, aftermarket demand is probably not very price sensitive. First, replacement parts sold to the ultimate consumer as part of a repair job will often be so urgent as to prevent the owners from spending significant time shopping for the most competitive supplier. ${ }^{64}$ Second, with the high cost of downtime, deterioration of the equipment and even possible personal injuries resulting from an inferior or improper repair, a slight increase in the odds favoring high quality and speed of repair work will justify large price increases. When the consequences of the use of substandard parts are combined with the logical reasons for assuming that OEM parts will be more reliable and combined with the common philosophy of "you get what you pay for", 65 it is not surprising that aftermarkets typically provide monopolistic profits, particularly to OEMs.

\section{B. Higher Costs of Independent Aftermarket Competitors}

Independents will often have higher cost than the OEMs because their volume of sales will not support the same economies of scale as the OEM and because of the lack of critically needed information or the cost and expense of obtaining such information.

\section{Higher OEM Volume}

Firms producing solely for the aftermarket will tend to have smaller requirements for parts than OEMs. ${ }^{66}$ There are a number of reasons for this including those discussed above in Part IIA. Even if that were not the case, however, aftermarket competitors would still tend to have smaller requirements than the OEM because the OEM buys or manufactures both for original equipment and

64. It seems likely that equipment owners do relatively little price shopping after the equipment has broken down. Jay Bock \& Jack Creamer, The Future of Distribution . . . is Likely to be Much More Disciplined!, Motor AGE, Dec. 1989, at 28. They will often, however, have past experiences with repair facilities that will assist them in making a selection of servicing organizations.

65. John Wirebach, Shelf Strategy Case Studies In Using Packaging and Pricing As Key Elements In Shelf Strategy, Automotive Marketing, Feb. 1968, at 27 (Private label parts must be sold below national brand prices with enough of a discount to "upset traditional buying habits .... [but] if the gap gets too large, you might make the consumer believe the product must be worthless.").

66. Firms manufacturing standardized parts used in a number of different products or brands of equipment will generally have larger volume than any single OEM. 
the aftermarket as well as for repairs under warranty. ${ }^{67}$ The larger volume will frequently permit lower production costs because of economies of scale. For some parts of almost every product, the combination of low replacement volume plus economies of scale will provide the OEM with a complete monopoly of parts that rarely need replacement. The higher volume will also often result in lower acquisition costs for parts purchased by the OEM.

Economies of scale and opportunities for the OEM to obtain monopolistic profits for parts unique to its equipment arise when per unit costs continue to decline at production levels higher than a firm selling solely in the aftermarket can expect to attain. ${ }^{68}$ Aftermarket competitors, actual or potential, will be unable to sell at prices which would force OEM prices to marginal cost. If the cost differences are sufficient, the OEM or its supplier will have a natural monopoly in such parts.

Even if the OEM buys instead of manufactures the part, it can obtain the lower price due to its supplier's lower per unit cost. The OEM, by its selection of suppliers, selects the firm that will attain the lower production cost. The lower production cost is then reflected in its lower prices. ${ }^{69}$ However, while that will benefit the OEM in its competition with other OEMs, it will not benefit the OEM in its competition with aftermarket competitors if its supplier sells to those competitors at the same price as to the OEM.

Even when the higher volume does not produce lower cost for the supplier, the supplier may be willing to give a large buyer a lower price than a smaller buyer or forego selling to the small buyer in order to keep the business of the larger buyer. ${ }^{70}$

Moreover because of the OEM's complete natural monopoly over the sale of some parts, wholesale or retail, competitors will have to buy the part from the OEM or its dealers. If the part is unavailable to competing repair services they will be unable to make needed repairs and will have to turn the job over to the OEM's dealers. Needless to say, if the OEM's dealers sell to competitors at all, they are unlikely to provide them with large discounts below retail price.

67. It is not clear whether the OEM may require that warranty repairs be made with OEM parts. Such a requirement as applied to anti-pollution equipment was prohibited under the 1977 amendments to the Clean Air Act, 42 U.S.C. $\$ 7541$ (1992). Even if not required, however, consumer preference for OEM parts combined with the fact that their cost is covered by the warranty will make it very difficult for independent aftermarket competitors to get much of the parts and servicing business provided under the warranty.

68. However, if per unit costs also continue to decline at production levels higher than the OEM's requirements, the OEM will obtain the lowest cost by contracting for the manufacture of the part by a third party also manufacturing parts for others. When the part is a standardized part widely used in other products, economies of scale, without more, are unlikely to contribute to supro competitive pricing by OEMs. In most cases the total demand for the part will be sufficient to support production at the most economic level by a number of firms. If not, and economies of scale are so great that they favor a level of production sufficient to support only one supplier for the parts used by all OEMs and others at the most economic production level, it will be that supplier, and not an individual OEM, that will be in a position to exploit any resulting economies of scale.

69. This is reflected by the fact that, in contrast to aftermarket margins, supplying parts to OEMs for original equipment "historically has been a low-margin low-return - on - equity - business." Kathleen Heaney, View From Wall Street; Profit Seekers Should take Interest in Auto Industry of 1990's, Automotrve News, Nov. 29, 1989, at 184.

70. Components sold to OEMs for original equipment are likely to carry a lower price than the same components sold in the aftermarket. Zelenitz 1980, supra note 47, at 113-14. 


\section{Independent Competitors' Lack of Information}

The cost of obtaining information is a factor not only in creating consumer willingness to pay more for OEM parts and services, but also a factor increasing costs for the OEM's aftermarket competitors. Current and relatively complete knowledge of the identity of the OEM's suppliers, the specifications and interchangeability of the parts of the original equipment and the OEM's prices is needed to produce or acquire the parts economically and to market them effectively.

The identity of the supplier to the OEM is important because as the manufacturer of the part for the original equipment it is often the highest volume and most efficient producer. Also, independents can counteract, at least partially, the preference for OEM parts if they can advertise that their parts are made by the supplier to the OEM. They cannot do either if they cannot identify the supplier of the part to the OEM.

Aftermarket competitors need the plans and specifications of the parts they will manufacture, have manufactured for them or use in the servicing of equipment. A part must be able to fulfill its function subject to the operating, temperature, pressure, chemical and other conditions to which it will be exposed when operating as a part of the equipment. The OEM, in the process of designing the equipment, will presumably have done any testing necessary to ensure the part's performance. If this information is available to aftermarket competitors only by redesigning the part by reverse engineering it will obviously be expensive.

Lack of knowledge of the OEM's parts specifications may also prevent the aftermarket competitor from countering the general preference for OEM parts by advertising that the parts equal or exceed the OEM's specifications. Parts interchangeability information is also often essential. ${ }^{71}$ This interchangeability is normally accomplished in the form of a part number. The OEM assigns a different number to each non identical part and, in its parts manuals, lists the part number of each of the parts used in each of its models. The part number informs the person making the repair which of the variety of parts generally serving the same function and having the same common name should be used to repair a specific piece of equipment identified by year, model or serial number. While that information can sometimes be obtained by the firm making the repair by looking at the part being replaced, that is not always true because the differences may not be apparent by simple observation. Manufacturing and wholesaling firms also require information on interchangeability to make the decisions on what parts to manufacture or stock, because the potential sales volume of the part will be greatly influenced by the number and popularity of the models in which the part is used.

Because of customer preferences for original equipment parts, aftermarket competitors must typically price their parts no higher than the OEM parts and often the price must be substantially lower. ${ }^{72}$ The OEM's price is, therefore, an important factor in the decision of an aftermarket manufacturer or wholesaler in deciding on whether to manufacture or stock a part. It is also a common

71. See generally, Voortman, supra note 13, at 240-43.

72. See supra Section IIA. 
strategy for aftermarket competitors to advertise their parts as cheaper than OEM prices. When current OEMs' price lists are not readily available considerable time and expense may be required to shop the dealers for their prices and obtaining wholesale prices may be impossible.

\section{PROPOSALS}

It is probably impossible to eliminate monopolistic aftermarket prices without draconian legislation such as price controls or utility type regulation. Both would undoubtedly do much more harm than good. As a first step to encourage aftermarket competition, however, Congress and the courts can avoid making matters worse. They can avoid enacting legislation like the Design Copyright Bill in its present form. In addition, I propose modifications and clarifications of the antitrust and copyright laws and legislation generally requiring disclosure of parts information.

Two premises underlie these proposals. First, an OEM that designs equipment with a combination of parts that accomplishes the purposes of the equipment more efficiently and reliably than competing equipment should be rewarded for the effort whether or not the design of the equipment or any of its components is patentable. Second, selling the equipment should be treated, at least absent an agreement to the contrary, as including a right for the buyer to use or have others use, for it, the design and information embodied in the components of the equipment. ${ }^{73}$ Though there are situations, such as described in Section IB in which aftermarket monopolies promote economic efficiency and should be allowed, for the reasons stated in Section IA, generally the reward for a better design of equipment should be in the form of a greater profit on the sale or lease of the equipment and not in the form of monopolistic profit on the maintenance of the equipment.

\section{A. Modifications and Clarifications of the Antitrust Laws}

OEMs commonly employ a wide variety of practices to entrench their positions by making information more costly to obtain and by preventing aftermarket competitors from participating in economies of scale. This section discusses those practices and the extent to which they are subject to attack under the antitrust laws. This Section also proposes modifications and clarifications to make the antitrust laws more effective in protecting competition in aftermarkets. It also suggests that some present interpretations of those laws are generating litigation which has no benefit to the public or may even be increasing the cost of aftermarket parts and services. A number of the suggestions made here would be moot if the legislation proposed in section IIIB and C were enacted.

The antitrust laws, particularly Sections 1 and 2 of the Sherman Act, ${ }^{74}$ are presently the chief legal basis for attacking practices resulting in monopolistic prices. Section 1 of the Sherman Act prohibits contracts, combinations and

73. This was the rationale of the House of Lords in British Leyland Motor Corp. v. Armstong Patent Co., [1986] 1 App. 577 (F.S.R. 591). See Claude Barfield \& Cynthia Beltz, Industrial Design Protection and A utomobile Repair Parts: Balancing Competition and Monopoly at Home and Abroad, AM. ENTERPRISE INST. 117-22 (1990).

74. 15 U.S.C. $\$ \S 1-2$ (1992). 
conspiracies ("agreements") in restraint of trade. Recognizing that all contracts have some restraining effect on the parties, the Act has long been construed to prohibit only "unreasonable restraints." generally tested by whether the agreement, on balance, is pro-competitive or anticompetitive. A restraint may be pro-competitive, on balance, because it increases efficiency or because, as in the case of patents, the restraint provides a necessary incentive to desired activity. The effect of a practice or competition is weighed in the context of a "relevant market." The definition of the relevant market is the often critical first step because it determines market share and market share is often the most important part of the analysis of effect on competition.

Where the issue is the relevant market for aftermarket parts or service there are several possible relevant markets depending on the circumstances. Thus, each separate non-interchangeable part may be a relevant market or parts for each brand of equipment may be separate relevant markets, as opposed to parts for all competing brands. The principle relevant market issue for purposes of the article, however, is whether aftermarket parts or services are a separate market from the market for the original equipment or part of a market that includes the original equipment and everything necessary to maintain and use the original equipment. The latter view depends on the theory that buyers are interested in the cost over time of performing the function for which the equipment is intended and is related to the argument, discussed above, that if the OEM raises aftermarket prices it will be forced to reduce original equipment prices correspondingly. That view was decisively rejected in Kodak and it is now clear that aftermarkets can be and often should be treated legally as relevant markets separate from the original equipment. ${ }^{76}$

Some kinds of agreements are "per se" unreasonable. That is, they are treated as unreasonable without any investigation of the overall economic effect of the agreement. Price fixing agreements, agreements between competitors to allocate customers or territories and agreements between competitors to boycott a supplier or customer are examples of "per se" illegal agreements.

Section 2 of the Sherman Act prohibits monopolization, attempts to monopolize and conspiracies to monopolize." To show "monopolization" a plaintiff must prove "(1) the possession of monopoly power in the relevant market and (2) the willful acquisition, maintenance or use of that power by anti-competitive or exclusionary means or for anti-competitive or exclusionary purposes." 78 Monopoly power has been defined as "the power to raise prices without losing so much business that the price increase is unprofitable." 9

75. Standard Oil Co. v. United States, 221 U.S. 1, 59-61 (1910).

76. Kodak, $112 \mathrm{~S}$. Ct. at 2080.

77. A conspiracy to monopolize would also, presumably, be a conspiracy in restraint of trade and it is not apparent that the conspiracy provision of Section 2 prohibits anything not already prohibited by Section 1 of the Sherman Act.

78. Kodak, 112 S. Ct. at 2089; Aspen Skiing Company v. Aspen Highlands Skiing Corporation, 472 U.S. 585, 595 (1985). See also, e.g., United States v. Grinnell Corp., 384 U.S. 563, 571 (1966); T.V. Communications Network, Inc. v. ESPN, Inc., 1991-1 Trade Cas. (CCH) \ 69,476, 66,016 (8th Cir. 1991).

79. Olympia Equipment Leasing v. Western Union Telegraph Company, 797 F.2d 370, 373 (7th Cir. 1986), cert. denied, 480 U.S. 934 (1987). 
The presence or absence of monopoly power is often inferred from market share, but the percentage of the market that may support such an inference is often unclear. ${ }^{80}$ In United States v. Alcoa ${ }^{81}$ Judge Hand stated that $90 \%$ was enough, $33 \%$ was not enough and that it was "doubtful" that $60 \%-64 \%$ was enough. More recent cases have held that $16 \%, 8220-25 \%^{83}$ and $32-35 \%{ }^{84}$ were not enough. In Colorado Interstate Gas Co. v. Natural Gas Pipeline, ${ }^{85}$ the court suggested that while the Supreme Court had "refused to specify a minimum market share ... lower courts generally require a minimum market share of between $70 \%$ and $80 \%$." It is clear, however, that factors other than market share are relevant to determining the existence of a "monopoly." 86

Attempted monopolization is established by proof of specific intent to control prices or destroy competitors by improper means, predatory or anti-competitive conduct directed toward that goal and a dangerous probability of success. ${ }^{87}$ The distinctions between Sections 1 and 2 are, therefore, that Section 1 requires some degree of collaboration, joint action, or at least, adherence (hereinafter "agreement") by two or more parties. ${ }^{88}$ That is not a requirement under Section 2, but Section 2 requires proof of actual or probable monopolization $-\mathbf{a}$ greater anticompetitive effect than is required under Section 1, particularly in Section 1 per se cases. Firms acting "unilaterally" have much greater freedom of action than firms acting together. Section 7 of the Clayton Act, ${ }^{89}$ Section 5 of the Federal Trade Commission Act, ${ }^{90}$ Section 3 of the Clayton Act ${ }^{91}$ and Section 2(a) of the Clayton Act as amended by the Act commonly known as the Robinson-Patman Act $^{92}$ may also be applicable to some of the practices.

\section{Denying Aftermarket Competitors Equal Access to the Most Efficient Suppliers}

The larger volume of the $\mathrm{OEM}^{93}$ or its supplier will frequently result in economies of scale and lower per unit costs. When the market for a part, usually a part unique to a single brand of original equipment, is sufficiently small in relation to the economies of scale in its production, no one other than the manufacturer of the part for original equipment will be able to manufacture and

80. See generally, Continental Trend Resources Inc. v. Oxy USA, Inc., 1991-2 Trade Cas. (CCH) \$69,510, 66239-66240 (W.D. Okla. 1991).

81. 148 F.2d 416, 424 (2d Cir. 1945).

82. Barry v. Blue Cross, 805 F.2d 866, 874 (9th Cir. 1986).

83. C.E. Serv., Inc. v. Control Data Corp., 759 F.2d 1241, 1245 (5th Cir. 1985).

84. Pennsylvania Dental Ass'n v. Medical Serv. Ass'n, 745 F.2d 248, 261 (3rd Cir. 1984), cert. denied, 471 U.S. 1016 (1985).

85. 885 F.2d 683, 694 n.18 (10th Cir. 1989), cert. denied, 111 S.Ct. 441 (1990).

86. Reazin v. Blue Cross \& Blue Shield, 899 F.2d 951, 968 (10th Cir. 1990); Shopping Bag v. Dillon Cos., 783 F.2d 159, 162 (10th Cir. 1986).

87. Abcor Corp. v. Am. Int'l, Inc., 916 F.2d 924, 926 (4th Cir. 1990); City of Vernon v. So. Cal. Edison Co., 955 F.2d 1361, 1365 (9th Cir. 1992).

88. A corporation, its subsidiaries and affiliated companies and their officers and employees are a single party for purposes of this rule. See Copperweld Corp. v. Independence Tube Corp., 467 U.S. 752 (1984) (overturning earlier, inconsistent precedents).

89. 15 U.S.C. $\$ 18$ (1992).

90. 15 U.S.C. $\$ 45$ (1992).

91. 15 U.S.C. $\$ 14$ (1992).

92. 15 U.S.C. \& 13 (1992).

93. See supra Section IIBI. 
sell the part at a competitive price. The OEM or its supplier will have a natural monopoly on the sale of the part. If the part is manufactured by the OEM or an outside supplier that resells only to the OEM, the part will generally be available only from the OEM'S dealers.

While demand for any single one of these "natural monopoly" parts will be small, the number of repair jobs that require one or more of such parts may be substantial. Competitive dealers and other repair facilities will regularly need some of these parts to repair the equipment and will be under a serious competitive handicap if forced to turn over to the OEM or its dealers all repair jobs which require the use of any such part.

The OEM whose strategy is to take its profit in the aftermarket has an obvious interest in denying aftermarket competitors access to its supplier. It is relatively easy and risk free for the OEM to do so when it manufactures the component itself, but more difficult when the part is manufactured for the OEM by another firm.

\section{a. Refusal to Sell to Aftermarket Competitors}

If the OEM does nothing more than refuse to provide products, information or services to a competitor, the competitor's options under existing law are limited principally to doctrines developed under Section 2 of the Sherman Act. While firms, including monopolists, are generally free to choose the parties with whom they deal, there are some limitations. Thus, a refusal to deal by a monopolist in an attempt to exclude competition without a legitimate business reason violates Section 2 of the Sherman Act. ${ }^{94}$ Moreover, under the similar "essential facility" or "bottleneck" rules a firm with a monopoly of a facility essential to its competitors' operations may be required under some circumstances to provide the facility to the competitors. ${ }^{95}$ To utilize that rule, a plaintiff must prove: (1) control of an essential facility by a monopolist of the facility; (2) inability of a competitor of the firm controlling the facility to practically or reasonably duplicate the facility; (3) the denial of the facility to the competitor; and (4) that it is feasible for the owner to provide the facility to the competitor. ${ }^{96}$ The feasibility test has been construed as requiring the plaintiff to prove that the owner of the essential facility had no "legitimate business or technical reason" for denying the facility to the competitor. ${ }^{97}$

Two major problems face an aftermarket supplier that seeks to use the essential facility rule to require an OEM to provide it with parts or information.

94. Aspen Skiing Co., 472 U.S. at 602-05; Otter Tail Power Co., 410 U.S. 366 (1973); Delaware \& Hudson Ry. Co. v. Consol. Rail Corp., 902 F.2d 174 (2d Cir. 1990), cert. denied, 111 S. Ct 2041 (1991).

95. Otter Tail Power, 410 U.S. at 366 (1973); United States v. Terminal R.R. Ass'n, 224 U.S. $383,405,409$ (1912).

96. Laurel Sand \& Gravel, Inc. v. CSX Transp., Inc., 924 F.2d 539, 544 (4th Cir.), cert. denied, 112 S. Ct. 64 (1991); Delaware and Hudson Ry. Co., 902 F.2d at 179; MCI Communications v. American Tel. \& Tel. Co., 708 F.2d 1081, 1132-1137 (7th Cir.), cert. denied, 464 U.S. 891 (1983).

97. Illinois ex rel Burris v. Panhandle Eastern Pipeline Co., 935 F.2d 1469, 1482-83 (7th Cir. 1991); Laurel Sand and Gravel, 924 F.2d at 544; MCI Communications, 708 F.2d at 1133; Hecht v. Pro-Football, Inc., 570 F.2d 982, $992-93$ (D.C. Cir. 1977); but see Delaware \& Hudson Ry. Co., 902 F.2d at 180 (expressly declining to consider whether a legitimate business purpose for the refusal would defeat an essential facility case). 
So closely interrelated are these problems that it may be more accurate to characterize them as facets of the same problem. First, the facility must be "essential." That is, denial of facility must give its owner the power to eliminate competition; the fact that denial of the facility may impose substantial costs on the competitor is not enough. ${ }^{98}$ Second, there is no clear rule as to the price at which the owner of the essential facility must sell. Presumably, the price attached to an offer to sell may be so high that it will be treated as a refusal ${ }^{99}$ because otherwise the essential facility rule would be completely meaningless. However, with one important exception, the courts have provided no guidance as to the limits of the monopolist's freedom to price its essential facility. The exception is that the owner may not retaliate against competitors by charging them a discriminatorily higher price. ${ }^{100}$

The present essential facility rule will usually not be a very effective method of eliminating monopolistic aftermarket prices. If the OEM sets the price in the aftermarket high enough so that aftermarket competitors can continue to operate without the facility or can pay the owner's price for the facility and still occupy a portion of the market, a court is likely to conclude either that the facility is not "essential," or that the owner has not "refused" to make it available, or that the price is reasonable. That might make the market for the part more "competitive" in the sense of "rivalrous" but would do little for consumers. To eliminate monopolistic pricing would require a rule compelling the OEM to sell to aftermarket competitors at marginal cost. However, it seems clear that the cost of attempting to control the pricing, either by regulation or through litigation, of all products in which there is a degree of legal natural monopoly power would be disproportionate to the benefits of possible reduction in parts' prices.

If the OEM sells to middlemen, such as dealers, from whom aftermarket competitors can buy the parts or services, there will usually be no remedy under the essential facility rule for the OEM's refusal to sell directly to aftermarket competitors. That is appropriate because the OEM should be in a position to offer dealers the incentive of an assurance that they will not be in direct competition with the OEM and the dealers are an alternative source of the parts. While an individual dealer may decline to sell parts to competitors and, even more likely, decline to sell parts at a discount from retail prices, unilateral action by individual dealers is unlikely to be effective in keeping the parts out of the hands of competitors. Some dealers will agree to sell parts to independents, particularly by transhipping to those located outside their own area, when there appears to be a reasonable prospect of keeping the sale secret and avoiding retaliation. The prospect of a quick, virtually expense free sale of a substantial

98. Alaska Airlines, 948 F.2d at 543-46; Twin Lab., Inc. v. Weider Health of Ill., 900 F.2d 566, 569-70 (2d Cir. 1990). See also MCI Communications, 708 F.2d at 1133; Olympia Equipment Leasing v. Western Union Telephone Company, 797 F.2d 370, 378-79 (7th Cir. 1986).

99. In Delaware \& Hudson Ry. Co., the Second Circuit held that an "unreasonable" price (an $800 \%$ increase over a prior price) constitutes "refusal." Delaware \& Hudson Ry. Co., 902 F.2d at 180. In Alaska Airlines, the Ninth Circuit expressly declined to take the position on that issue. The court also concluded that there had been no refusal because there was no indication that the defendants had "ever set this fee at a level that would drive their competitors away." Alaska Airlines, 948 F.2d at 545.

100. United States v. Terminal R.R. Ass'n, 224 U.S. 383, 410-11 (1912); MCI Communications, 708 F.2d at 1132-33. 
volume to aftermarket competitors of the OEM will overcome the purely "ethical" considerations of some of the OEM's dealers.

If, on the other hand, the OEM sells only to end users and in quantities which do not permit them to become resellers, the essential facility rule should require the OEM to sell the parts to aftermarket competitors. The problem of selecting the appropriate price can be resolved by prohibiting discrimination against competitors. The OEM should be required to sell to aftermarket competitors at a price no greater than its price to end users unless the OEM can justify the higher price by higher costs of selling to the aftermarket competitors. ${ }^{101}$ That will leave the OEM with some advantage over its aftermarket competitors because they will be buying some parts at the same price as their customers but in most cases the advantage will not be overwhelming because the "natural monopoly parts" will constitute only a small percentage of the total cost of the repair.

\section{b. Preventing Dealers From Selling to Aftermarket Competitors}

OEMs may go beyond refusing to sell directly by attempting to restrain their dealers from reselling parts to independent wholesalers and dealers. ${ }^{102}$ If they do so by entering into "agreements" with their dealers the agreements will be within the scope of Section 1 of the Sherman Act.

The legal status under Section 1 of OEM imposed restraints on dealers' sales to independents is not entirely clear. ${ }^{103}$ Vertical (between supplier and customer) manufacturer imposed restraints limiting the territories and customer classes to which a dealer can resell are subject to the rule of reason rather than the per se rule. ${ }^{104}$ They can be justified on a showing that the restraints increase the effectiveness of the manufacturers competition by, for example, serving as a necessary inducement to distributors to carry and promote the manufacturer's products. Restraints on intrabrand competition are permitted in the interest of more effective interbrand competition.

However, interbrand competition receives no apparent benefit when the principal purpose and effect of the restraint is to impose additional cost and burdens on the OEM's aftermarket competitors. Territory and customer restraints imposed on dealers should be held unreasonable and illegal under Section 1 of the Sherman Act if they prevent aftermarket competitors from buying parts at prices no higher than dealers are charging their customers who purchase similar or lower volumes.

The OEM may be reluctant to enter into restrictive agreements with its dealers for fear of antitrust liability but attempt to accomplish the same result by adopting a policy of refusing to sell, or sell at the same terms, to firms that resell to independents. That will often be an ineffective tactic because dealers

101. There will still be difficult pricing problems in some cases. For example, when the OEM sells the part only in a package with repair service, it would be necessary to separate the price of the parts from the price of the labor.

102. Dimidowich v. Bell \& Howell, 803 F.2d 1473 (9th Cir. 1986), modified on other grounds, 810 F.2d 1517 (1987).

103. An agreement between the OEM's dealers, however, would not only be unenforceable but a per se illegal group boycott under Section 1 of the Sherman Act.

104. Continental T.V., Inc. v. GTE Sylvania, 433 U.S. 36 (1977). 
will have an incentive to supply aftermarket competitors outside their own area. Competitors will generally be able to find a source unless dealers are restricted from supplying them not only by "agreements", but by agreements that are legally enforceable. It is particularly unlikely to be effective unless dealers are aware of the policy.

However, the combination of measures taken by the OEM to inform dealers and to enforce the policy plus dealer adherence by refusing to sell to independents may be held to constitute an "agreement" within Section 1. It has been held that a tacit understanding or knowledge that concerted action is contemplated plus adherence is sufficient ${ }^{105}$ but the present status of the law on what constitutes an "agreement" within Section 1 is unclear. ${ }^{106}$

Proof of an agreement has been made more difficult in many cases. Vertical restraints, such as retail price fixing and restrictions on dealers as to the territories in which, or customer to which, they may sell, may be in the ultimate interest of the OEM, but are normally imposed for the immediate benefit of dealers. When one dealer violates the restraint, other dealers may complain. The combination of dealer complaints plus termination of the offending dealer was probably the most frequent basis for dealer suits alleging that their termination violated the antitrust laws. That combination was also generally enough to get the case to the jury. However, in Monsanto ${ }^{107}$ and again, in Business Electronics $v$. Sharp Electronics ${ }^{108}$ the U.S. Supreme Court held that such proof was insufficient to prove an illegal agreement under Section 1.

Despite the more restrictive interpretation of the "agreement" requirement of Section 1 of the Sherman Act, an OEM relying on a refusal to deal to enforce restrictions on dealers still faces substantial risk that a court may find an agreement under Section 1. Dealers anxious for the OEM's business may state to the OEM their intention to comply with the OEM's policy. That will create an issue of whether the statement was purely voluntary or the result of express or tacit solicitation of such statements by the OEM and, therefore, constitutes an "agreement." Similarly, the threat of the loss of a good dealer may cause the OEM to give the offending party a "second chance." Or, efforts to identify violators may involve cooperation with other dealers or suppliers. Any of the foregoing may result in a finding that there is a tacit agreement.

105. American Tobacco Co. v. United States, 328 U.S. 781 (1946); Interstate Circuit Inc. v. United States, 306 U.S. 208 (1939); Standard Oil of California v. Moore, 251 F.2d 188 (9th Cir. 1957).

106. Initially, in United States v. Colgate, 250 U.S. 300, 304-05 (1919), the Court held that a firm was free to choose with whom it would deal. Despite the per se illegality of retail price fixing, Colgate could legally announce that it would refuse to deal with retailers that cut prices and it could carry out that threat. Subsequent cases, however, greatly eroded the Colgate rule, holding, for example, that any policing of compliance with the policy would convert what was otherwise a unilateral refusal to deal into an "agreement" prohibited by Section 1. The Colgate rule, while never expressly overruled by the Supreme Court, was so eroded by United States v. Parke Davis Co., 362 U.S. 29 (1960) and the cases discussed therein, that it seems safe to say that, in effect, if it was illegal to enter into an agreement restricting a practice of suppliers or customers, compliance with the sellers' desires obtained by refusal to deal, or threat of refusal to deal, was also illegal. Recently, however, Colgate has been given new life. See Monsanto Co. v. Spray-Rite Service Corp., 465 U.S. 752, 761 (1984).

107. 465 U.S. 717 (1984).

108. 485 U.S. 717 (1988). 
Adding to the risks of attempting to enforce restraints by refusal to deal is the fact that the personnel in contact with the dealers may not fully understand the subtle distinction between firms that comply, possibly quite enthusiastically, with the restraint because they want and depend on their competitors to do so, and firms that "agree" to do so. It will be difficult to keep the record free of oral and even written statements constituting evidence of an "agreement."

Consequently, attempting, by refusal to deal, to enforce restraints that would be illegal under Section 1 if accomplished by an agreement, entails significant antitrust risk and is likely not to be very effective.

c. Preventing Suppliers from Selling to Aftermarket Competitors or from Selling to Them at the Same Price as to OEMs

\section{i. Competitive Effect}

When economies of scale are such that production costs per unit continue to decline at production levels higher than the total demand for the part for the OEM's brand, and there are available suppliers who are making the part, or similar parts, for a broader market, economies of scale favor the OEM's purchasing rather than manufacturing the part. ${ }^{109}$ In addition, capital requirements and other factors may cause the OEM to prefer to buy rather than manufacture the part. To preserve its ability to impose higher costs on its aftermarket competitors when purchasing the part, however, the OEM must restrain its supplier from selling to aftermarket competitors ${ }^{110}$ or, at least, from selling to them at the same price as to the OEM.

Such restraints have the obvious, immediate anti-competitive effect of increasing aftermarket wholesaling and retailing competitors' costs, and as noted above $^{\prime \prime \prime}$ make it more difficult for aftermarket wholesaling and retailing competitors to counter OEM advertising of "genuine" parts. There will sometimes also, however, be pro-competitive effects as when an aftermarket monopoly will increase efficiency. ${ }^{112}$

109. The OEM could become a marketer of similar parts to others but lack of experience, reluctance to buy from a competitor or the danger that additional capacity would drive prices down to the extent that the investment in the additional capacity could not be recovered will often make that an unattractive alternative.

110. Section III.A.2.b infra covers agreements under which suppliers are given "confidential" plans and specifications for parts to manufacture for the OEM and agree to keep the information confidential and use it only to produce parts for the OEM. See Christianson v. Colt Industries Operating Corp., 613 F. Supp. 330 (C.D. Ill. 1985), rev'd, 870 F.2d 1292 (7th Cir. 1989), cert. denied, 493 U.S. 822 (1989), opinion on remand, 1991-1 Trade Cas. (CCH) $\$ 69,415,65,676,65,680$ (C.D. I11. 1991).

111. See supra Section II.B.2.

112. See supra Section I.B. Also, the restriction will sometimes result in the creation of a second manufacturer of a part that would otherwise be the monopoly of the supplier to the OEM. While that will sometimes be beneficial, it will often do little for consumers. When economies of scale favor a single producer, the addition of a second producer with higher cost is not likely to reduce parts prices. Since the OEM is in a position to determine which firm will be its supplier and thus enjoy the original equipment business that supports the economies of scale, that supplier will not be in a position to take monopoly profits. Aftermarket competitors will benefit more from buying from that supplier at the same prices as the OEM than from buying from a different but higher cost competitor. 
Agreements restricting a supplier of standardized parts to a single OEM are neither very common nor usually very dangerous to competition. Standardized parts used in several OEMs' equipment will normally be manufactured by a number of suppliers all producing at efficient levels. In the infrequent instances where that is not the case and there is a monopolistic supplier of a necessary part, no OEM's volume will be sufficient to induce the supplier to forego the right to sell to others.

What is more common, however, both for standardized and unique parts are announcements from parts suppliers that they supply only OEM's and their price schedules containing, in addition to volume discounts, an "OEM price" which is lower than the prices available to aftermarket competitors for shipments of equal size. Such sales and pricing policies are undoubtedly adopted in large part because the supplier understands that the policies increase its chances of getting OEM business. The supplier's understanding may be based on threats made in a public announcement by the OEM or more subtle methods. The understanding may also be incorrect.

When the suppliers respond to the perceived threat of missing or losing OEM business and rigorously follow their announced policies and price schedules, the effect on aftermarket competition is no different from a legally enforceable agreement restricting the supplier. Such rigorousness is probably uncommon. It is in the supplier's interest to sell to both the OEM and to anyone else willing and able to pay if it can avoid retaliation by the OEM. Thus, while the supplier has an incentive to convince the OEM that it will not sell to competitors, it also has an incentive to "cheat" and make such sales if it can do so without the OEM discovering it. The same is true if an aftermarket competitor offers to make a substantial purchase if given the same price as the OEM. OEM efforts to prevent suppliers from dealing with aftermarket competitors through the use of "refusal to deal" will have antitrust risks at least as great as when used to prevent dealer sales to aftermarket competitors and are likely to be even less effective.

ii. Application of the Antitrust Laws To OEM Restrictions on Suppliers' Sales to Aftermarket Competitors

The foregoing analysis suggests that measures taken by OEMs to prevent suppliers from selling to others must be judged on the facts of each case. It also suggests that in the case of suppliers of parts unique to a single OEM, there should be a presumption of anti-competitive effect requiring the defendant to introduce evidence of a pro-competitive effect, such as evidence of its investment in supplier training, in order to avoid liability.

Arguably that is the current law where the restrictions on supplier's sales to others is by an "agreement" 113 within the scope of Section 1 of the Sherman Act. ${ }^{114}$ While such agreements are not, and should not be, per se illegal, a

113. The discussion in Section III.A.1.b, supra, of when an OEM attempts to use "refusal to deal" as a method of controlling dealer conduct will constitute an agreement within Section 1 is fully applicable to attempts to restrict suppliers' sales.

114. Section 3 of the Clayton Act will not apply because it applies only to "sales on the condition" that the buyer not purchase from others. It is directed only at restrictions imposed on customers by 
balancing of the pro and anti-competitive effects as is done in rule of reason cases produces the results suggested above. ${ }^{115}$

Logically, one could go a step further and declare, by legislation or construction of the antitrust laws, that OEM refusals to deal with suppliers because the suppliers sell to aftermarket competitors at all or at the same price as to OEMs is illegal and declare that suppliers' refusals to sell to aftermarket competitors because of the OEM's policy are agreements within Section 1 of the Sherman Act. There is nothing pro-competitive about such refusals and sales policies to balance against their obvious anti-competitive effect.

Because of the availability of the private treble damage action, such rules would undoubtedly generate a great deal of litigation, much of it frivolous, and prevent efficiency enhancing changes of suppliers. Every supplier termination would be at risk of a lawsuit claiming that the termination was to prevent sales to aftermarket competitors. Similarly, every supplier that refused to sell to an aftermarket competitor would be at a similar risk. That refusal to deal is probably not a very effective method of preventing suppliers from selling to others. It is probably best to ignore such OEM policies, and suppliers' reactions to them, unless there is an "agreement" within section 1 or a monopolization or attempt to monopolize under section 2 as those acts are presently construed."16

When suppliers "unilaterally" give OEMs a lower price, the Robinson Patman Act may be applicable. Sections 2(a) and 2(f) ${ }^{117}$ respectively prohibit discriminating in price between competitors if the result may be to substantially lessen competition with the seller or the favored customer and buyers from inducing discrimination. The Act applies only to the sale of commodities and not services ${ }^{118}$ and is subject to the exceptions that permit discrimination where justified by a cost savings in selling to the favored customer - the "cost justification" defense - or where necessary to meet competition - the "meeting competition" defense.

The parts supplier's sales would be within the scope of the Robinson Patman Act if the parts are resold by the OEM in the aftermarket, but not if the OEM uses them in manufacturing new equipment. The OEM's "knowing receipt" of an illegal lower price will expose the OEM to liability under Section 2(f) of the Act. However, because of the large volume of purchases by the OEM, there will usually be numerous firms willing to grant discounts and the suppliers selected by the OEM will often have a meeting competition defense.

sellers, not at restrictions imposed on sellers by customers. It could, however, become applicable indirectly through section 5 of the Federal Trade Commission Act. See Hershey Chocolate Corp. v. F.T.C., 121 F.2d 968 (3rd Cir. 1941).

115. In Kodak there were agreements between Kodak and its parts suppliers restricting them from selling to aftermarket competitors which were found to be illegal. They were found to be illegal, however, not because of their impact on parts prices, but as part of a per se illegal tying arrangement whereby Kodak's power over its parts market was used to obtain a monopoly in the market for servicing Kodak equipment. Kodak, 112 S. Ct. at 2077-78.

116. A possible alternative which would reduce the risk of excessive lawsuits would be to enact legislation restricting the right to refuse to deal in these circumstances, and to provide legislation enforceable only by federal, state or local law enforcement agencies. Private actions would be prohibited.

117. 15 U.S.C. $\$ 13$ (1992).

118. Ball Memorial Hosp., Inc. v. Mutual Hosp. Ins., Inc., 784 F.2d 1325, 1340 (7th Cir. 1986), reh'g denied 788 F.2d 1223 (7th Cir. 1986). 
In addition, liability under the Robinson Patman Act requires two sales at different prices. It can always be avoided by not selling to a firm at all. Thus, where the disparity between the potential orders from the OEM and the size of the potential orders from aftermarket competitors is large, the supplier that fears Robinson Patman Act liability is likely to solve the problem by refusing to sell to independents at any price. That is helpful neither to aftermarket competitors nor to consumers.

Finally, by giving suppliers an argument to use in resisting customer pressure for lower prices, the net impact of the Act may come closer to raising all parts prices to the higher level paid by aftermarket firms rather than reducing aftermarket prices to OEM levels. It seems at least as likely that repeal of the Robinson Patman Act would lower aftermarket prices as would more vigorous enforcement of the Act.

\section{d. Tooling Arrangements}

As noted above, when per unit cost continues to decline beyond production levels required to supply a single OEM, economies of scale favor purchase of the part rather than vertical integration into producing the part by the OEM. In the case of parts unique to a single brand of original equipment, however, manufacture of the unique part will often require specialized inputs, such as tooling which the outside parts supplier does not use in its other operations. Because of the limited potential demand from other buyers, parts suppliers may be reluctant to assume the cost of obtaining the tooling.

Where the tooling, as a practical matter, can be transferred between potential suppliers of the part, an obvious solution is for the OEM to purchase, retain ownership of, and provide the tooling to, whichever supplier offers the best terms from time to time. Such arrangements are referred to herein as "tooling arrangements" because they most commonly apply to tooling, but they could also be used for other kinds of specialized inputs. The problem with tooling arrangements is that, as would be expected, the agreements normally provide that the tooling will be used only in producing parts for the OEM, a restriction that will often have an anti-competitive effect.

When the per unit cost of using the tooling continues to decline at production levels higher than an aftermarket competitor could expect to sell, the effect of tooling arrangements is to create a differential between the OEM's costs and the costs of aftermarket competitors. When the supplier provides its own tooling, the cost of the tooling will normally be reflected in the price of the product and each buyer pays for it in proportion to the amount of its purchases. Smaller purchasers get a portion of the benefit of the economies of scale made possible by the large purchaser's orders. The large buyer also receives a proportional benefit from the orders of the smaller buyers but the net effect (absent seller price discrimination) is that large and small buyers have the same cost when the seller owns the tooling. In contrast, if an OEM can restrict use of the tooling to production for its orders, aftermarket competitors will often be excluded, resulting in an increased differential between the costs of the OEM and aftermarket competitors.

Even if some aftermarket supplier duplicates the tooling and manufactures the part, there will be waste in that a needless set of tooling will be produced. 
Also, because of the necessity to amortize the tooling over smaller volume, the aftermarket supplier will have higher costs than the OEM. Thus, when economies of scale in the use of inputs other than tooling favor purchase of the part, restricting the use of the tooling allows the OEM to obtain the same advantage over aftermarket competitors as the OEM obtains by in-house manufacture. The OEM will be able to obtain monopolistic profits in the aftermarket because no one else will be able to compete effectively except at prices above the OEM'S cost.

Since the restriction on the use of the tooling to manufacturing for the OEM is part of the agreement by which the tooling is provided, it is within the literal scope of Section 1 of the Sherman Act. It is however, a restriction imposed by the OEM on the use of its own property which may be necessary to providing the tooling and, therefore, pro-competitive.

Whether tooling arrangements are pro or anti-competitive on balance depends in part on the availability of alternative, less restrictive, methods of getting the supplier to make the investment in the tooling when providing the OEM's requirements is necessary to give the supplier sufficient volume to amortize the investment. The obvious substitutes are agreements to purchase a sufficient quantity to justify the supplier's investment in the tooling. Requirements or fixed amount contracts covering a period of time are common contractual devices for a number of purposes and can be used to give the supplier sufficient security to be willing to make the investment necessary to manufacture and sell the part at competitive prices. Drafting a contract to govern the sales which will occur in the future is often difficult, however, because it requires anticipating and providing for the changes which may occur. Moreover, attempting to assure future competitive prices by contract may involve higher transaction costs and be a less reliable method of controlling costs than contemporaneous competition. It cannot be assumed that forward contracting is always a satisfactory substitute for tooling arrangements.

Clearly, restrictions in tooling arrangements have mixed effects on competition. They have a generally anti-competitive effect, but often less anti-competitive than the alternative methods of obtaining investment in the tooling necessary for manufacture of the parts. Moreover, tooling is subject to wear and OEMs could not justly be required to provide its use free of charge when used to make parts for competitors. Ruling that tooling arrangements limiting the right to use the tooling to production for the OEM are illegal will thus either eliminate the use of such agreements or require the courts to make decisions on the proper price for the use of the tooling on a case-by-case basis, a responsibility the courts probably would, and should, reject.

In the absence of persuasive evidence indicating that tooling arrangements are a major factor contributing to monopolistic parts prices, it is probably best to treat tooling agreements restricting the use of tooling as at least presumptively, if not per se, legal.

\section{e. Discounts Based on Long Production Runs}

The generally larger requirements of an OEM enable it to place larger orders and to negotiate a discount because longer production runs reduce setup costs. However, the supplier will attempt to combine production for the OEM's orders 
with orders from other suppliers, including aftermarket competitors. By offering the same price incentives to the aftermarket competitors, suppliers can set up even longer production runs to further lower production costs. When set up costs are appreciable, combining orders is pro-competitive because it increases efficiencies and tends to lower supplier's costs and prices.

An OEM's interests are not always served by combining orders and charging all customers a uniform price. Increasing the size of production runs by filling the OEM's orders in the same run as smaller orders from others will reduce supplier's costs and prices to all customers, however; in comparison to manufacturing each customer's orders on a separate production run, combining orders reduces costs and prices on a per unit basis much more to the smaller customers than to the OEM. Therefore, the OEM loses a part of its advantage over aftermarket competitors.

To preserve its advantage the OEM may try to prevent the supplier from combining its orders with the orders of aftermarket competitors in a single production run. If a supplier agrees not to manufacture for an OEM's competitors as part of the same production run, the agreement would probably violate Section 1 of the Sherman Act. Agreements to treat the size and timing of the OEM's orders as confidential would probably pass antitrust scrutiny, but such agreements would be much less effective. They would inhibit the ability of aftermarket competitors to initiate negotiations for lower priced productions orders by combining their orders with an OEM's. These agreements, however, would not prevent the supplier from soliciting business for the same time as the OEM's production run and reflecting the cost reductions in its price to all customers.

The OEM's tactic may also run afoul of the Robinson Patman Act's prohibition of price discrimination. The supplier and the OEM may argue that the OEM's larger orders make possible the longer production runs, which justifies a lower price. That argument is unlikely to prevail where the OEM has taken measures to prevent the supplier from combining orders. Customers' orders contribute to the cost reduction resulting from longer production runs in proportion to the size of the order. The general rule is that the seller "must charge all costs to all customers on some calculus of proportionality . ..."119

\section{Restricting the Dissemination of Information}

To effectively restrain OEM parts pricing, aftermarket competitors must know the plans and specifications of OEM parts, the OEM's parts information, the parts' interchangeability, the identity of the OEM's suppliers, and the OEM's aftermarket prices. This gives OEMs an incentive not to disseminate this information to aftermarket competitors. ${ }^{120}$ Their ability to do so depends largely on whether the information has been protected as a trade secret.

To be a trade secret, information must be developed within the firm, generally unknown to others, disclosed only to those with an express or implied obligation to preserve its secrecy, valuable to the firm that developed it, and costly for a

119. Frederick W. Rowe, Price Discrimination Under the Robinson Patman Act 305 (1962). See also id. at 269-72, 281.

120. The legislation requiring OEMs to make information available to aftermarket competitors which is proposed in Section III.B.1 would, if enacted, moot the issues raised in this section III.C.2(c). 
competitor to duplicate. ${ }^{121}$ The antitrust laws will not prevent the OEM from protecting trade secrets against use by aftermarket competitors.

To the extent that the OEM can keep trade secret information "in house" by manufacturing the parts itself and providing sales and maintenance services directly, rather than through dealers, aftermarket competitors seeking to obtain the information will have to rely on the essential facility doctrine, under Section 2 of the Sherman Act. Even though reaffirmed in Kodak, however, the essential facility doctrine does not appear likely to provide a broadly useful remedy because of the problem of setting a price for the information. Unlike setting a price for "natural monopoly" parts discussed above, using the price at which information is sold to others will not work because generally there is no "sale" of the information. The information is incorporated as part of the original equipment, parts or services provided by the OEM.

Usually the OEM will be required to give others the information. For example, suppliers providing unique parts to the OEM will need its plans and specifications and when dealers are needed to do maintenance and carry inventories of parts, they will need interchangeability and price information. The desire to preserve its relationship with the OEM may cause the supplier or dealer to refuse to provide the information to an aftermarket competitor. However, providing the information may enable the supplier or dealer to make additional sales, providing an incentive to "cheat." Even if the OEM is aware of the "leak", it may still be difficult to identify the source. Also, if the OEM stops dealing with a supplier or dealer, the incentive to comply with the demands or desires of the OEM is likely to disappear. The terminated dealer will sell the information for whatever it can get. Legally enforceable confidentiality agreements will be required to prevent aftermarket competitors from obtaining and using OEM information which has been disseminated. While such agreements are within the scope of Section 1 of the Sherman Act, agreements to keep information confidential have not, without more, been held to violate the antitrust laws. Thus, so long as the OEM's information continues to meet the requirements of a trade secret, it can be used to obtain monopolistic profits. That will not always be possible, much less practical.

\section{a. Agreements to Conceal the Identity of Parts Suppliers}

Suppliers are likely to broadcast the fact that they are supplying the OEM, unless the OEM prevents them from doing so. The preference for OEM parts ${ }^{122}$ will aid the seller in efforts to sell directly to consumers, wholesalers and retailers. To prevent such competition, the OEM may require that the supplier not publicize the fact that it is the OEM's supplier. In addition or in the alternative, the OEM may prohibit the supplier from placing its own trademark on the parts. The extent to which lists of suppliers and information about them are trade secrets if adequately protected by contract is unclear. ${ }^{123}$ The general rule is that the more

121. SI Handling Systems, Inc. v. Heisley, 753 F.2d 1244, 1256 (3rd Cir. 1985); Restatement of Torts § $757 \mathrm{cmt}$. b (1939). See generally, Roger M. Milgrim, 1 Milgrim on Trade Secrets $\$ 2$ (1967).

122. See supra Part II.A.

123. See MILGRM, supra note 121 , at $2-303$. 
valuable the information to competitors and the more expensive it is to for them to obtain the information by independent means, such as reverse engineering, the more likely the information will be treated as a trade secret. ${ }^{124}$ Put another way, the more anti-competitive it is to preserve the trade secret, the more likely it is to be protected.

The effect of successfully preventing competitors from identifying the supplier is similar to the effect of prohibiting the OEM's supplier from selling to competitors. If the supplier is unknown it may be impossible to buy from it. The aftermarket competitor may be buying the part from the same supplier as the OEM but not know it. The inability to advertise that fact to consumers decreases consumer information.

I have found no judicial opinions expressly covering the legality of agreements denying firms the right to publicize the fact that they supply the OEM. However, if the agreement is successful in making it difficult for aftermarket competitors to identify the OEM's supplier, it should be illegal under Section 1 of the Sherman Act in the same circumstances as agreements expressly restricting the supplier to selling only to the OEM.

\section{b. Agreements to Conceal Plans and Specifications for Parts}

When a third party manufactures a unique part for the OEM, the OEM will typically provide the plans and specifications subject to an agreement that they remain the property of the OEM, are kept confidential, and are used solely to produce the part for the OEM. ${ }^{125}$ This protects their trade secret status and keeps the parts out of the hands of aftermarket competitors. The trade secret status may be lost when the parts are embodied in equipment put on the market if the parts can, be readily reproduced by examination or reverse engineering. The critical factor will often be the degree of difficulty and expense of duplicating the part without the benefit of the plaintiff's plans and specifications. ${ }^{126}$ In addition, a number of courts have granted some relief when a trade secret was lost because putting the product on sale made reverse engineering possible. They have enjoined a competitor from using information obtained in breach of an express obligation of confidentiality or assessed damages for its use. ${ }^{127}$

If the OEM's restrictions on suppliers last no longer than trade secret laws protect the information, they should not present antitrust problems. The restriction in the agreement is ancillary to the agreement to manufacture and supply the product to the OEM. This agreement may be pro-competitive as compared to the OEM's manufacturing in house. If the agreement restricts the supplier for a longer period than is reasonably necessary to reverse engineer the product, the

124. Restatement of Torts $\S 757 \mathrm{cmt}$. b (1939); S.I. Handling Systems, 753 F.2d at 1256; See Sigma Chemical Co. v. Harris, 794 F.2d 371 (8th Cir. 1986) (holding that a secret list of chemical suppliers created at great cost by plaintiff and which would have been difficult for competitors to reproduce constituted a trade secret).

125. See e.g., Rockwell Graphics Systems, Inc. v. Dev. Industries, Inc., 925 F.2d 174 (7th Cir. 1991).

126. MilgRIM, supra note 121 , at $\S 2.05[2]$ and [3].

127. Specifically, courts have enjoined the use of such information for the amount of time by which defendant's putting the product on the market was shortened by its misconduct. Schulenberg v. Signatrol, 212 N.E.2d 865, 869-870, 33 Ill.2d 379 (1965); Northern Petrochemical Co. v. Tomlinson, 484 F.2d 1057, 1061 (7th Cir. 1973); Kubik, Inc. v. Hull, 224 N.W.2d 80, 95 (Mich. Ct. App. 1974). 
agreement is anti-competitive. It should be held to violate Section 1 of the Sherman Act when applied to aftermarket competitors copying of OEM parts.

Some states have enacted legislation or adopted rules designed to restrict copying or make it more expensive. Challenges to the legality of such provisions have met with mixed results. ${ }^{128}$ Such state statutes and rules should be held to be in conflict with the federal antitrust laws if applicable to aftermarket competitors.

\section{c. Agreements to Conceal Price and Part Number Information}

OEMs typically provide their dealers with parts books and price lists for each model they produce. These materials identify each part with the description, the part number, and the price. That part number is used only for parts that are identical or interchangeable. With the information in a set of parts books, competitors familiar with the system can determine which models use the same part to fulfill a particular function.

The importance of this information to competitors is apparent ${ }^{129}$ and duplicating it without the OEM's parts books and price lists will be expensive and time consuming, particularly when the equipment is complex and comes in a number of models. Parts interchange data and price lists will meet the tests for a trade secret as long as they are kept "in-house" or disclosed only to those who have a duty to keep them confidential. ${ }^{130}$ To preserve its trade secret status and to prevent it from getting into the hands of aftermarket competitors, the OEM may require dealers to agree to treat the information as confidential. In addition, the OEM may prohibit its suppliers of standard parts from putting their own part numbers on the parts because supplier part numbers can be used by aftermarket competitors to determine the interchangeability of standard parts.

The courts have decided the legality of agreements between original equipment manufacturers and their distributors or customers not to disseminate appear not to have parts books or the interchange and price information they contain. However, the general rules under Section 1 of the Sherman Act seem clearly applicable to such agreements. They are anti-competitive because they raise competitors' costs without a counterbalancing pro-competitive effect.

\section{Tying Arrangements}

The OEM may condition the grant of a dealership or sales to consumers on the dealers' or consumers' agreement to purchase aftermarket parts or services from the OEM or its dealers. Such tying arrangements or "tie-ins" are generally

128. Interpart Corp. v. Italia, 777 F.2d 678, 684-685 (Fed. Cir. 1985) (upholding California "plug molding" statute which prohibited the use of plug molds, a process "substantially less expensive than developing a mold from scratch") Id. at 684. Contra Vault Corp. v. Quaid Software, Ltd., 655 F. Supp. 750, 762-763 (E.D. Louisiana 1987), aff'd, 847 F.2d 255, 268-270 (5th Cir. 1988) (holding that a Louisiana statute permitting computer programs licenses to prohibit the licensee from "reverse engineering" the program was invalid because inconsistent with federal copyright law); Merchant Suppliers Paper Co. v. Photo-Marker Corp., 285 N.Y.S.2d 932, 934-936 (App. Div. 1967) (holding that when equipment sold, seller could not impose a restriction on its use which would prevent it from being reverse engineered).

129. See supra Part II.B.

130. The cases involving price books go both ways, probably because they are very fact specific. MLGRIM, supra note 121 , at $\S 209$ [8] [b]. 
said to be per se illegal under Section 1 of the Sherman Act and Section 3 of the Clayton Act ${ }^{131}$ if the seller has market power in the tying product and a significant amount of commerce in a separate, tied product is affected by the tying arrangement. ${ }^{132}$

Kodak defined the required economic power as "the power to force a purchaser to do something that he would not do in a competitive market ... the ability of a single seller to raise price and restrict output." ${ }^{133}$ Market share is frequently treated as a surrogate for the economic power to coerce the buyers to buy other products ${ }^{134}$ but the market share indicative of market power or its absence is not clearly established. ${ }^{135}$

A legitimate business purpose can justify an otherwise per se illegal tying arrangement. Business justifications may include the necessity of guaranteeing a high quality product as a way of breaking into the market. ${ }^{136}$ However, the defendant may be required to prove that there was no other way of accomplishing the same purpose which would have been less restrictive of competition. ${ }^{137}$

The "two separate products" criteria is often critical in tie-in cases. The test suggested for the existence of separate products is whether the products can be selected and provided separately consistent with economic efficiency. ${ }^{138}$ This depends on whether the demand for each can be separated. ${ }^{139}$

\section{a. Tie-ins Imposed on Dealers}

OEM's may condition appointing a firm as a dealer in the original equipment on the dealer's agreeing either not to buy parts from aftermarket competitors, or to buy all or most of the parts it requires from the OEM. This eliminates or severely restricts the dealer's ability to buy parts from anyone else. ${ }^{140}$ Even without an agreement of any kind, the OEM may provide better delivery terms, a larger allocation of desired models, or other forms of favoritism to the dealers who are more faithful in buying parts from the OEM. It may decline to renew the dealership of those dealers who do not buy sufficient OEM parts. This is

131. 15 U.S.C. $\S 14$. Section 3 of the Clayton Act prohibits sales "on the condition, agreement or understanding that the buyer will not use or deal in" (emphasis added) the product of a competitor where the effect of the condition "may be to substantially lessen competition." (emphasis added) It applies generally to exclusive dealing or requirement contracts imposed by sellers on buyers. The effect of the "may be" language is to make it applicable to agreements which have no present anticompetitive effect but are likely to do so in the future. It appears, however, only to sales of "commodities" not sales of services. Satellite Television \& Associated Resource, Inc. v. Continental Cablevision of Virginia, Inc., 714 F.2d 351, 538 (4th Cir. 1983).

132. Jefferson Parrish, 466 U.S. at 13-21 (1984); Northern Pacific Railway Co., 356 U.S. at 6.

133. Kodak, 112 S. Ct. at 2080-81.

134. Id.

135. Compare Osborn v. Sinclair Refining Co., 286 F.2d 832 (4th Cir. 1960), reaff'd, 286 F.2d 832 (4th Cir. 1961) (10\% sufficient to indicate economic power) with Jefferson Parrish, 466 U.S. at $26(30 \%$ not sufficient without more to infer market power).

136. Grappone, Inc. v. Subaru of New England, Inc., 858 F.2d 792 (1st Cir. 1988); Mozart Co. v. Mercedes Benz of North Amer., Inc., 833 F.2d 1342 (9th Cir. 1987).

137. Mozart Co., 833 F.2d at 1342; Metrix Warehouse v. Daimler-Benz Aktiengesellschaft, 828 F.2d 1033 (4th Cir. 1987); Susser v. Carvel Corporation, 323 F.2d 505 (2d Cir. 1964).

138. Kodak, 112 S. Ct. at 2080; Jefferson Parrish, 466 U.S. at 21-24. See Christianson v. Colt Industries Operating Corp., 1990-91 Trade Cas. (CCH) \ 69,415, 65,678-89 (C.D. Ill. 1991).

139. Kodak, 112 S. Ct. at 2080, Dimidowich, 803 F.2d 1473, 1480-1481 (9th Cir. 1986), modified on other issues, 810 F.2d 1517 (1987).

140. Metrix Warehouse, 828 F.2d at 1037 nn.7 \& 8 . 
particularly likely when the OEM is selling the original equipment at an artificially low price in the expectation of receiving high margins on the sale of parts.

The overall effect on competition of such restrictions is unclear. An immediate anti-competitive effect seems apparent as the restriction deprives aftermarket manufacturing competitors of a prime market for the parts - the OEM'S dealers. This may decrease competition in parts manufacturing.

Market power can exist at the distribution level as. well as at the manufacturing level. If dealers have a monopoly in their territories, increasing manufacturing competition will shift the power to obtain monopolistic profits from the manufacturer to the distributors. That will not benefit consumers. Moreover, aftermarket manufacturing competitors may develop distributors of their own or go into distribution of the parts themselves if they are deprived of the OEM's dealers as an outlet. This will generate additional competition in distribution of the parts. In addition, when the OEM is selling to only one dealer in an area, ${ }^{141}$ a requirement that the dealer buy the OEM'S parts may be necessary to ensure that the OEM's parts are properly represented and that the equipment is properly serviced. ${ }^{142}$

Restricting the dealer to the OEM'S parts may also minimize deception. ${ }^{143}$ A significant part of the public probably assumes that the OEM'S dealers will carry only the OEM'S parts and expect repairs on their equipment to be made with OEM parts. That expectation is most likely to be fulfilled if the dealer has no other, or at least no cheaper, parts available.

"Agreements" not to carry replacement parts produced by aftermarket competitors which are anti-competitive in effect are prohibited as unreasonable restraints under Section 1 of the Sherman Act and by Section 3 of the Clayton Act. Under Section 3, only a potential anti-competitive effect need be shown. ${ }^{144}$ Therefore, no special per se rule is needed for tying arrangements to prevent anti-competitive OEM restrictions on dealers carrying competing lines of replacement parts. The rule may prevent efficiency improving restrictions on dealers and it should be abandoned as applied to such arrangements. Moreover, the market power test for application of the per se rule to tie-ins works poorly to prevent monopolistic parts prices or to prevent "unfair" treatment of dealers and may prohibit pro-competitive restrictions on dealers.

The tie-in cases involving dealerships generally allege that the original equipment is the tying product and that the parts are the tied product. ${ }^{145}$ This makes the OEM's market share in the original equipment the focus of interest in determining market power. ${ }^{146}$ That seems questionable in the case of OEMs requiring dealers to carry OEM parts. The tie-in is imposed on the dealer, not the consumer, and the tying product that creates any leverage that exists is not

141. It is beyond the scope of this article to discuss when such agreements are pro-competitive and anti-competitive.

142. Grappone, 858 F.2d at 792.

143. Metrix Warehouse, 828 F.2d at 1038 (defense rejected by the court on the ground that other methods could have been used).

144. See supra note 131 .

145. Grappone, 858 F.2d at 792.; Mozart Co., 833 F.2d at 1342; Metrix Warehouse, 828 F.2d at 1037.

146. Grappone, 858 F.2d at 793. 
just the ability to purchase the original equipment but the dealership as a whole. ${ }^{147}$ The value of the dealership and the amount of leverage it creates to force dealers to buy parts from the OEM is not necessarily related to the OEM's market share for the original equipment. A dealership for a less popular brand can be more valuable than a dealership for a brand with a large market share if the OEM for the less popular brand offers larger margins, a larger, better-protected territory or other more favorable terms. To the extent that market power is focused on market share, the inquiry should be directed at the market for dealerships. However, if a dealer's facility and goodwill are closely tied in the public mind to a particular product and a particular brand of that product, the OEM will have considerable power to impose new requirements on its dealers. This is true regardless of the availability of other dealerships or the brands market share unless the dealers have protected themselves by contractual provisions.

\section{b. Tie-ins Imposed on Consumers}

Direct tying agreements with consumers requiring them to buy only aftermarket parts and services produced or wholesaled by the OEM or its dealers seem to be relatively uncommon. Theoretically, these agreements can monopolize the aftermarket though they will often be very difficult to enforce.

The deciding question in consumer tie-in cases is whether the original equipment and its maintenance are a single product fulfilling the function the original equipment is designed to serve or whether it is a product separate from the replacement parts and other maintenance services. If there is a single product, the tie in rule is inapplicable. The test for single versus separate products which is best designed to serve the purposes of the antitrust laws is whether competition in original equipment will eliminate the possibility of monopolistic pricing for the combination of the original equipment and its maintenance. Under that test, original equipment and replacement parts are separate markets. ${ }^{148}$

Competition in both the original equipment and the aftermarket more effectively protects consumers than competition in the original equipment and monopoly in the aftermarket. However, in some circumstances an OEM aftermarket monopoly may be more efficient and produce lower consumer prices or more competition in the original equipment. ${ }^{149}$ Therefore, tying arrangements between original equipment and aftermarket parts and services should never be treated as per se illegal. That is particularly true when the agreement for the purchase of the original equipment clearly informs buyers that they will be required to obtain aftermarket parts or services from the OEM or its dealers.

147. The fact that it is the dealership which is the tying "product" rather than any item the dealership buys or sells is supported by cases such as Roberts v. Elaine Powers Figure Salons, Inc., 708 F.2d 1476 (9th Cir. 1983); Warriner Hermetics, Inc. v. Copeland Refrigeration Corp., 463 F.2d 1002 (5th Cir. 1972), cert. denied, 409 U.S. 1086 (1972); Siegle v. Chicken Delight, 448 F.2d 43 (9th Cir. 1971), cert. denied, 405 U.S. 955 (1975) holding the franchise or trademarks to be a tying item distinct from the product or services purchased. Contra Kugler v. Aamco Automatic Transmissions, Inc., 460 F.2d 1214 (8th Cir. 1972).

148. See supra Section I.A.2.

149. See discussion of metering, quality control and risk allocation in Section I.B supra. See also W. David Slawson, Excluding Competition Without Monopoly Power: The Use of Tying Arrangements to Exploit Market Failure, ANTTtrust Bull., Summer 1991, at 457 (arguing that market power is largely irrelevant to effect of a tie-in on competition). 
Existing law should be more radically revised when applied to OEM practices which sell the original equipment and aftermarkets parts and services only as a package. Examples of such practices include lease only policies and long term warranties requiring that the OEM's parts and services be used for maintenance and repair. These practices are within the definition of tying arrangements because one cannot purchase the original equipment without effectively agreeing to get parts and service from the OEM. ${ }^{150}$ However, they are unlikely to have anticompetitive results or raise prices. Aftermarket competition is required because the buyer of original equipment is locked into parts compatible with that equipment, but does not and cannot know the future price of the parts. ${ }^{151}$ This reasoning is inapplicable to aftermarket monopolies resulting from lease only policies or warranties because the price of parts and services covered by a warranty is paid at the time of purchasing the original equipment. In the case of a lease which the lessee can terminate if the lessor changes the terms, not only is the full price known but there is no "lock in" effect.

It is true that monopolization of one product by a tying arrangement employed by a firm with market power in another market requires an entrant to enter at both levels and may restrict entry. ${ }^{132}$ This will rarely be a factor relevant to the competitive effect of tying arrangements. Entering the market for the original equipment will require any OEM to enter the parts market regardless of whether tying arrangements are in effect. There may be exceptions where the repair parts and maintenance services are standard parts and readily available from numerous sources, but buyers will generally demand assurance that aftermarket parts and services will be available before they buy the original equipment. Therefore, the fact that aftermarket competition is prevented by a refusal to sell equipment except as part of a package including repair parts and services should not be a basis for finding that refusal to be illegal.

\section{Vertical Integration}

In general, the more completely the OEM is able to integrate vertically, the more effectively and safely it can impose added costs on its aftermarket competitors. It can control its facilities that produce and distribute its parts and equipment to consumers and do so without any agreement within the scope of Section 1 of the Sherman Act.

. Integrating "backward" into the manufacture of parts permits the OEM to sell the part at a price that reflects the higher cost of manufacturing the part in the smaller quantities that aftermarket competitors can expect to sell. Both backward integration into parts supply and forward integration into distribution and maintenance increase the ability of the OEM to keep parts information and the parts themselves out of the hands of aftermarket competitors. It is generally easier, and certainly safer under the antitrust laws, for a firm to control the activities of its own employees than to control the activities of independent firms. Vertical integration, however, is not always economically feasible and can entail its own antitrust risks.

150. That was recognized even in the dissenting opinion in Kodak, 112 S. Ct. at 2095.

151. See supra Section I.A.2.

152. Fortner, 394 U.S. at 509. 


\section{a. Economic Restraints on Vertical Integration}

Vertical integration into the manufacture of parts will increase the OEM's manufacturing costs when economies of scale favor production at levels higher than the OEM's requirements. It will then be cheaper to buy the parts than to manufacture them. Vertical integration into distribution usually presents even greater problems.

If equipment is composed of parts that will wear out unevenly or are susceptible to breakage and the equipment is valuable enough to justify repair it will be unmarketable unless the purchaser has assurances that someone has the information, the skill and the parts necessary to do the job. When that information must be disseminated to third parties, aftermarket competitors are more likely to acquire it. Vertical integration into maintenance of the equipment can sometimes be so complete that the OEM is the only one that will need the parts information to repair the equipment is possible. However, this will require either that the equipment be sent to the OEM's manufacturing facilities, that the OEM create numerous local facilities to perform the maintenance, or that the OEM send its personnel and equipment to the customer's location. The first alternative will be impracticable in the case of bulky equipment and likely to meet buyer resistance. The latter two alternatives involve large capital requirements or expenses for the OEM. Any of the alternatives require a willingness on the part of users of the equipment to forego any competition in repair, including the ability to do in-house repairs and maintenance.

Forgoing competition may be acceptable or even demanded when the product is novel or highly technical and there is no established group of firms other than the OEM capable of adequately maintaining and repairing the product. For the most part, purchasers who have an alternative will be unwilling to put themselves so completely in the hands of a seller unless they have some way of controlling repair costs by contract or the seller assumes the risk of breakdown either by a lease rather than a sale of the equipment or by a long term and very complete warranty.

\section{b. Vertical Integration by Internal Growth versus by Acquisition}

When vertical integration is economically practical and the OEM can create the capacity to produce or distribute the parts, the antitrust laws provide no reliable way of preventing OEMs from vertically integrating to take monopoly profits in the aftermarket. The OEM can refuse to provide parts and information to competitors without agreement with anyone. Its refusal will be subject to the restraints of Section 2 of the Sherman Act that are limited in scope and will not force OEM parts prices to a competitive level.

Growth by internal expansion requires the creation of additional capacity which may be unprofitable for the OEM. That will tend to be the case when there is already adequate or even excess capacity. If the OEM creates additional capacity, prices may be forced down to the point where the OEM cannot obtain a return on its investment.

The obvious solution is to buy existing capacity that will not add to total capacity and not create additional downward pressure on price. However, acquisitions of stock or assets are subject to Section 7 of the Clayton Act as well as Section 1 of the Sherman Act. 


\section{c. Section 7 of the Clayton Act}

Section 7 of the Clayton Act prohibits acquisitions of stock or assets where "the effect may be to substantially lessen competition in any line of commerce in any section of the country." It is applicable to both horizontal (between competitors) and vertical (between suppliers and customers) mergers. An acquisition agreement may also constitute a violation of Section 1 of the Sherman Act. ${ }^{153}$

While vertical integration by acquisition often increases efficiency, for example, by reducing transaction costs, in some situations it also reduces efficiency and has anti-competitive effects. When the total volume of a part supports only a single supplier, the most efficient and pro-competitive result occurs when the OEM purchases the part from an outside supplier who (1) will be restrained from obtaining monopolistic profits by the OEM's ability to switch suppliers and (2) will sell to aftermarket competitors at the same price as to the OEM. When the OEM acquires stock or assets in lieu of purchasing from such a supplier, the acquisition forecloses competitors from the largest and most economical source of supply. This foreclosure is a basis for holding vertical acquisitions of suppliers illegal under Section 7 of the Clayton Act. ${ }^{154}$ The vertical acquisition cases generally involve foreclosure of competitors of the supplier from the market represented by the customer firm by foreclosing buyers from a source of supply that is, or may become, particularly important because of the large market share or lower costs. ${ }^{155}$ When the OEM's only advantage of the acquisition is to prevent aftermarket competitors from access to the lowest cost source of supply, ${ }^{156}$ the acquisition should be held illegal under Section 7 .

\section{Failure of OEMs to Compete in Each Others Aftermarkets}

Competing OEMs of the same products could be each others most effective aftermarket competitors, particularly for standard parts. They will have the relatively high volume and the economies of scale that result from purchasing parts for both original equipment and their own aftermarket. They will also have

153. The two statutes have long been thought, however to play different roles. Section 1 has been construed as prohibiting only agreements having an actual anti-competitive effect while Section 7 is an incipiency statute forbidding acquisitions that have no immediate anti-competitive consequences but have a potential for an adverse effect in the future. Minnesota Mining \& $\mathrm{Mfg}$. $\mathrm{v}$. New Jersey Wood Finishing Co., 381 U.S. 311, 323 (1965); United States v. Penn-Olin Chemical Co., 378 U.S. $158,170-171(1964)$. The continuing validity of that distinction has recently been thrown into question. In United States v. Rockford Memorial Corp., 898 F.2d 1278 (7th Cir.), cert. denied, 111 S. Ct. 295 (1990), the court stated that over the years the construction of Sections 1 and 7 had converged so that now "both statutes as currently understood prevent transactions likely to reduce competition substantially." Id. at 1281-82.

154. Brown Shoe Company v. United States, 370 U.S. 294, 328 (1962); Heatransfer Corp. v. Volkswagenwerk A. G., 553 F.2d 964, $981-982$ (5th Cir. 1977); United Nuclear Corp. v. Combustion Engineering, Inc., 302 F. Supp. 539, 555 (E.D. Pa. 1969).

155. United States v. Kennecott Copper Corp., 231 F. Supp. 95, 104-105 (S.D. N.Y. 1964), aff'd per curiam, 381 U.S. 414 (1965); Filtrol Corp. v. Slick Corp., 1970 Trade Cas. (CCH) 973,035, pp.88,052, 88,053 (C.D. Cal. 1969), aff'd per curiam, 70 T.C. 173,292 (9th Cir. 1970); See also, Combustion Engineering, Inc., 203 F. Supp. at 556; Record Club of America, Inc. v. Capital Records, Inc., 1971 T.C. $\$ 73,694$ at 90,899 (S.D. N.Y. 1971).

156. Brian S. Moskal, Adapt and Survive; Avoiding the Graveyard of Auto Partsmakers, INDUSTRY WK., June 29, 1987, at 26-27 (trend in auto industry is to out source more parts from less expensive suppliers). 
the greater credibility that comes from being a large, well known company. It will be more difficult to characterize a competing OEM as a "fly-by-night" operation. However, it does not appear that OEMs actively solicit the parts business of the dealers of competing OEMs. While there are exceptions, ${ }^{157}$ OEMs seldom attempt to provide their dealers with parts and information to service competing brands. Little, if any, advertising's directed at consumers to use the parts sold by one OEM on equipment manufactured by a competing OEM.

Agreements between OEMs not to compete in each other's aftermarkets are per se illegal conspiracies. However, the cases do not reflect the existence of such agreements and there is no reason to believe that such agreements are common. An agreement is rarely necessary to convince an OEM to exercise restraint in soliciting the aftermarket business of competing brands. Each OEM's knowledge that it would invite retaliation if it moved vigorously into its competitor's aftermarkets is sufficient to explain the lack of aftermarket competition. Advertising parts for competing brands of equipment would undercut consumer directed advertising campaigns for "genuine" parts because the implied premise of such advertising is that the parts sold by an OEM are the best and cannot be reliably duplicated by anyone else.

\section{Avoiding the Use of Standardized Parts}

Economies of scale rarely add to the OEM's power to charge monopolistic prices for standardized parts used in a variety of types of equipment. ${ }^{158}$ Whether OEMs purposely design equipment to use unique parts solely to obtain monopolistic profits ${ }^{159}$ in the aftermarket is uncertain. A disadvantage to that strategy is that designing and manufacturing unique parts usually costs more than the use of standard parts. Thus, the supra-competitive profits on replacement parts must compensate for the added cost of both the original equipment and the replacement parts before producing a net gain.

That would require a relatively large aftermarket in comparison to the original equipment market. There are markets such as the razor/razor blade markets in which the market for replacement parts is much larger than the market for the original equipment. In such markets a large incentive exists to design aftermarket parts that are non-standard and incompatible with competitors' original equipment. Under these circumstances some of the reasons that aftermarket monopolies permit monopolistic pricing for the original equipment combined with its maintenance are less applicable. One of those factors is that the owner is "locked" into parts which are compatible with the equipment and the OEM can either exclusively provide or provide more cheaply than others. Where the cost of the equipment is small in relation to the cost of the aftermarket items, the "lock" is weaker because the owner of the equipment will discard it sooner. He will

157. Myram Borders, Big Three Market Spares, U.P.I., Nov. 17, 1983, financial section. (interview with W. Blair Thompson) (five year plan of GM's auto components groups is to get more outside business). See also W. Blair Thompson; The five-year plan of GM's auto components group is to get more outside business Automotrve News, July 18, 1988 (90\% of the sales of GM-built components are for original equipment and $10 \%$ for aftermarket).

158. See supra Section III.A.1.c.(1).

159. The economic effect of such "predatory innovation" is argued in Sidak, supra note 53, and in Ordover et al., supra note 53. 
replace it with a different brand with lower aftermarket prices. In addition, purchasers are more likely to obtain comparative parts pricing information when parts prices will be the largest portion of the cost of using the equipment.

While some parts are manufactured differently from standard or previously used parts solely to avoid aftermarket competition, these instances are vastly outnumbered by the designs that vary for technological or other business reasons. The cost of allowing this monopoly is smaller than the cost of permitting every different design to be challenged in an antitrust case. It would be sound policy to rule, as a matter of law, that antitrust liability could not be based on a decision to use unique parts.

\section{B. Modifications of Copyright Law to Protect Information on Interchangeability of Parts Between Competing Brands of Equipment}

The importance of parts and price information to aftermarket competitors has been previously discussed in sections II.B.3.b and c above. OEMs have made that information more difficult to obtain by copyrighting the parts books and price lists. A number of circuit courts previously followed the "industrious collection rule," that held compilations of information which was collected "industriously" or by the "sweat of the brow" could be protected by copyright. ${ }^{160}$ The United States Supreme Court recently rejected that rule, holding that a copyright protects only the format and selection of the compiled material and not the information itself. ${ }^{161}$ Therefore, copyright should no longer prevent aftermarket competitors from using the parts interchangeability and pricing information in the OEM's parts books.

The ability to copyright the "selection" may, however create a dangerous ambiguity. If a compilation involves enough selectivity to be copyrightable it may be argued that copying any part of the compilation is infringement. That seems clearly incorrect. Copying the "selection" means copying the first compiler's decisions as to what should be included in and excluded from the compilation. If the second compiler makes independent selections there is no copying of the copyrightable element of the compilation, even if information about the companies selected is copied from the first compilation. That should be made clear either by court decision or by legislation.

At the same time, the industrious collection rule fulfilled an important function. Collecting data, such as information on the interchangeability of parts between competing brands of equipment from scattered sources such as the parts books of a number of OEMs can be expensive. However, such information is highly useful to aftermarket competitors who attempt to provide parts and service for multiple brands. Firms that track down the information and compile it from the OEMs' parts books or other sources need some form of legal protection for the information as well as for the form in which it is presented. While calling that protection "copyright" is inconsistent with the concept that a copyright does not protect information, protection similar to copyright should be available for

160. See generally Voortman, supra note 13.

161. Feist Publications, Inc. v. Rural Telephone Service Corporation, Inc., 111 S. Ct. 1282 (1991). See also Bellsouth Advertising and Publishing Corp. v. Donnelley Information Publishing, Inc., 933 F.2d 952 (11th Cir. 1991) (format of yellow pages protected, not information itself). 
the information. That will provide the incentive to create interchange books.

That protection should not extend to the OEM's information on parts interchangeability between models produced by the same manufacturer and to parts prices contained in the OEM's parts books and price lists. That information is not "industriously collected" from anywhere. It is the reflection of the design and pricing decisions of the OEM. ${ }^{162}$ If the OEM is allowed to keep the information from competitors it can extract a monopoly profit from its use because it can charge a higher price for parts. It is information which the OEM must and will collect in the course of designing its various models of the equipment and the OEM can charge for that work in the price of the equipment. This protection should be available only to those firms that compile data collected from external sources; not for compilations disclosing the interchangeability of parts solely between an OEM's own models.

\section{Legislation Protecting Designs and Requiring Disclosure of Information}

While the foregoing suggestions for clarifying and modifying the antitrust and copyright laws should encourage aftermarket competition, they are far from a complete solution to the problem of monopolistic aftermarket prices, particularly as it results from lack of information by customers and competitors. I suggest legislation broadly requiring disclosure of information to consumers and aftermarket competitors combined with protection against use of the information by equipment manufacturing competitors. Initially, the legislation should protect OEMs against copying by competing OEMs of their original parts designs and specifications and of the other information related to parts embodied in their original equipment. ${ }^{163}$ The protection should, like a copyright, protect against copying but not against use of a design, even though identical, which was arrived at independently. The protection should exist without any need for registration of the design or information though some form of notice might well be required.

Unlike existing copyright law, however, the legislation should include protection of improvements and functional elements of the design. ${ }^{164}$ Most importantly, unlike existing copyright and patent rights, the right would not be against the world but only against use in competition with the designer's equipment. There would be, in effect, a royalty free license to use the design and information to compete in the aftermarket for the OEM's equipment.

Finally, the legislation would require OEMs to make information about their original equipment parts available at the request of customers and of persons or firms seeking to compete in the aftermarket. The required information would include the identity of any outside suppliers and sufficient details of the plans

162. That is closely parallel to the telephone numbers in the white pages telephone directories which were involved in Feist. In each case the information is not so much "collected" as "decided" by the compiler.

163. This proposal is not applicable to those elements of parts designed by the OEM or anyone else which are different from the part as embodied in the original equipment and designed specially for the aftermarket. Such elements should be awarded the same degree of protection, whether under trade secret law or new legislation, as other designs.

164. See supra Section 3.B. 
and specifications of the part to permit duplication. ${ }^{165}$ The OEM would be required to provide the information at a price no greater than the approximate cost of communicating it to consumers and aftermarket suppliers. ${ }^{166}$

It seems clear that enactment of legislation along the lines proposed here would make aftermarkets more competitive and reduce the prices of aftermarket parts and services. The principal reasons for monopolistic aftermarket prices are lack of information by consumers and competitors and lower OEM costs resulting from the economies of scale and ability to negotiate more favorable terms which result from the OEM's greater requirements. This proposal would provide information directly to relatively sophisticated consumers and independent aftermarket competitors. In addition it would provide information to unsophisticated consumers who would not themselves review the specifications because it would enable quality aftermarket competitors to duplicate or improve on the OEM's parts and advertise that their parts matched or exceeded OEM specifications. Similarly, it would improve the chances that aftermarket competitors will be able to buy from the OEM's supplier because they would at least be able to identify the supplier. The fact that parts are equal to OEM parts and made by the same supplier is the kind of simplified information likely to be useful to those buyers who would not examine the specifications themselves. Identification of the OEM's supplier will enable the independent wholesaler and retailer competitors to at least attempt to buy from the firm which will often be the lowest cost producer of the part.

The principle problem with the proposed legislation is that requiring disclosure of information, much of which would otherwise be protectable by trade secret law, might remove an important incentive to invest in improving parts design. However, the cost of designing parts that increase the value or decrease the cost of the original equipment can be largely recouped on the sale of the equipment if competing OEMs are prevented from copying. ${ }^{167}$ Undoubtedly there also will be some leakage in the case of parts which are inherently superior in some respect and which competing OEMs would wish to incorporate into their own equipment. Parts manufactured with the information produced pursuant to this law will occasionally end up in competing equipment. That should be more than compensated for by the protection that the proposed legislation gives the designer against OEM competitors copying through reverse engineering. No

165. The law would not cover secret techniques for manufacturing the part. If others desire to copy such techniques they presumably reflect improvements for which the developer of the technique should be compensated. That is different from the specifications and configuration of parts which usually need to be copied not because they are inherently superior but simply to mesh with the other components of the equipment.

166. A less radical variation of this proposal would be to make obtaining a copyright, with the accompanying obligation to provide information, optional. The problem is that probably very few OEMs would select that option unless the design of the part reflected an improvement which could be utilized in competing equipment and most such designs would be patentable. The law would not be used where it is needed most - when the only thing special about the parts is that they have been designed to mesh with the other components of the original equipment.

167. This may appear inconsistent with the argument in Section I.B that reducing aftermarket prices will not enable the seller to obtain the same profit by increasing prices for the original equipment. However, the principal basis for that argument is that the value to the buyer of any existing OEM policy of low aftermarket prices must be discounted because the policy may be changed. In contrast, the value to the buyer of any superior components embodied in the original equipment is a value which the buyer certainly obtains and does so immediately upon purchase of the equipment. 
additional incentive in the form of monopolistic aftermarket prices is required.

While the law would undoubtedly result in some litigation there is no reason to believe that the cost of the litigation would be any greater than the costs now incurred in administering programs to preserve, and in litigating the alleged theft of trade secrets related to aftermarkets. The foregoing proposals should decrease both the cost of aftermarket parts and services and the combined cost of purchasing and maintaining equipment over its lifetime without jeopardizing the incentive to invest in research and development of improved designs of parts and equipment. 